http://dx.doi.org/10.18778/7969-549-2.03

Kamil Brzeziński

Uniwersytet Łódzki

\title{
Wykorzystanie programu komputerowego QDA Miner w analizie jakościowego materiału badawczego na przykładzie pogłębionych wywiadów swobodnych z mieszkańcami tódzkich gated communities
}

Streszczenie. Głównym celem niniejszego artykułu jest przedstawienie procesu analizy jakościowego materiału badawczego przy wykorzystaniu oprogramowania komputerowego - programu QDA Miner. W artykule przedstawione zostaną różnice między prowadzeniem analizy badawczej w sposób tradycyjny a procesem analitycznym wspieranym komputerowo. W tym celu wykorzystano pogłębione wywiady swobodne przeprowadzone z mieszkańcami łódzkich osiedli zamkniętych, tzw. gated communities.

Warto odnotować, że pakiety komputerowe z rodziny CAQDAS, wspierające pracę badaczy jakościowych, cieszą się coraz większą popularnością, w tym również wśród polskich naukowców. W polskich periodykach naukowych coraz częściej można spotkać artykuły dotyczące praktycznego wykorzystania tego typu programów. W publikacjach tych omawiane są przede wszystkim: NVivo, Atlas.ti, MAXqda czy Opencode. Natomiast rzadziej dotyczą one programu QDA Miner, co może świadczyć o jego mniejszej popularności. Przybliżenie możliwości wsparcia procesu badawczego z wykorzystaniem niniejszego oprogramowania wydaje się więc uzasadnione.

Słowa kluczowe: gated communities, badania jakościowe, analiza jakościowa, analiza wspomagana komputerowo, QDA Miner.

\section{Jakościowe techniki badawcze}

Uwe Flick (2010), definiując pojęcie „badania jakościowe”, podkreśla, że przez długi czas było używane w dość specyficzny sposób - jako wskazanie alternatywy dla badań ilościowych, co ściśle wiązało się z falą krytyki tych ostatnich, która nasiliła się zwłaszcza w latach 60. i 70. XX w. Jednak wraz z upływem czasu oraz w miarę dalszego rozwoju badań jakościowych znaczenie samego terminu stawało się coraz bardziej precyzyjne. W chwili obecnej nie jest on już definiowany przez negację, jako badania nie-ilościowe, nie-standaryzowane, lecz poprzez odniesienie do swoistych i charakterystycznych cech. Jak podkreśla Flick (2010), badania 
jakościowe zamiast liczb używają tekstu jako materiału empirycznego. Mają również na celu bliższe przyjrzenie się światu zewnętrznemu oraz opis, interpretację, a niekiedy wyjaśnienie zjawisk społecznych z perspektywy wewnętrznej, na wiele rozmaitych sposobów, w tym m.in. poprzez: analizę doświadczeń jednostek i grup; analizę interakcji i aktów komunikacji w czasie ich trwania czy analizę dokumentów (Flick 2010). Na swoiste zalety badań jakościowych zwraca uwagę Earl Babbie (2007), który uważa, że jedną z kluczowych zalet tego typu badań jest całościowa perspektywa oraz możliwość uzyskania głębszego i pełniejszego zrozumienia danego zjawiska. Co więcej, jego zdaniem badacze terenowi mogą rozpoznać zdecydowanie więcej niuansów w postawach i zachowaniach badanych, które mogą zostać niedostrzeżone przez badaczy stosujących inne metody (Babbie 2007). Niemniej należy zdawać sobie sprawę, że zarówno badania ilościowe, jak i jakościowe mają zalety i wady, a sam wybór metody w znacznym stopniu jest determinowany przedmiotem i problematyką badania. Babbie, za Johnem i Lyn Lofland, wymienia kilka elementów życia społecznego, które najlepiej kwalifikują się do przeprowadzenia badania terenowego, a są to m.in.: działania zwyczajowe, spotkania, epizody, role, związki, grupy, organizacje, miejsca zamieszkania, a także światy społeczne i style życia (Babbie 2010, za: Lofland 1995).

Powyższa skrótowa charakterystyka metod jakościowych nie ma na celu ich gloryfikowania i dowodzenia, że przewyższają one metody ilościowe, a jedynie ukazanie, że pewne elementy rzeczywistości społecznej lepiej badać za pomocą technik jakościowych. Warto zauważyć, że przez długi czas istniał konflikt między zwolennikami jednych i drugich metod, wynikający przede wszystkim z pozytywistycznej epistemologii badaczy ilościowych i interpretatywnej - jakościowych (Scott, Marshall 2005). Obecnie nadal można spotkać zadeklarowanych zwolenników metod ilościowych, niedoceniających badań jakościowych, a także "jakościowców” podważających sens stosowania tzw. „ilościówki”. Wydaje się jednak, że przynajmniej w pewnym stopniu spór ten został zażegnany. $W$ tym miejscu można wspomnieć chociażby o próbie pogodzenia różnych podejść do badań społecznych poprzez zaproponowaną przez Normana Denzina strategię triangulacji ${ }^{1}$ polegającą na wykorzystaniu różnych metod, perspektyw teoretycznych i źródeł danych (Scott, Marshall 2005). Ponadto, o pewnym zażegnaniu konfliktu może świadczyć także coraz większa popularność tzw. Mixed Methods Research, które łączą w sobie zarówno techniki jakościowe, jak i ilościowe. Burke, Onwuegbuzie i Turner (2007: 123) definiują to podejście w następujący sposób:

${ }^{1}$ W oksfordzkim słowniku socjologicznym (Scott, Marszall 2005) podano następującą definicję triangulacji: „The use of at least three, but preferably multiple studies, theoretical perspectives, investigators, and data-sets for research on one issue or theme. In particular, the combined use of micro-level and macro-level studies, using each to complement and verify the other, in order to achieve robust research results" (por. Konecki 2000: 85-86). 
Mixed methods research is the type of research in which a researcher or team of researchers combines elements of qualitative and quantitative research approaches (e.g., use of qualitative and quantitative viewpoints, data collection, analysis, inference techniques) for the broad purposes of breadth and depth of understanding and corroboration.

Powyższa definicja w znacznym stopniu wpisuje się w logikę triangulacji metodologicznej², którą Krzysztof T. Konecki, za Denzinem, definiuje jako użycie wielu metod do zbadania pojedynczego problemu (Konecki 2000: 86, za: Denzin 1970). W kontekście rosnącej popularności Mixed Methods Research warto jeszcze dodać, że autorzy artykułu Toward a Definition Mixed Methods Research wskazują, iż opisywane przez nich podejście zyskiwało popularność już od lat 60. XX w. W swoim opracowaniu wymieniają aż 19 definicji Mixed Methods Research zaproponowanych przez różnych badaczy i naukowców (Konecki 2000: 86, za: Denzin 1970). Co więcej, definiują i opisują różne rodzaje i odmiany Mixed Methods Research, co w znacznym stopniu dowodzi coraz większej popularności tego podejścia i sukcesywnego wygaszania konfliktu między „ilościowcami” a „jakościowcami”. Należy jednak zaznaczyć, że przedmiotem niniejszego tekstu nie jest geneza rozwoju podejścia łączącego metody ilościowe z jakościowymi ani odtworzenie konfliktu między badaczami jakościowymi i ilościowymi, lecz ukazanie możliwości wykorzystania oprogramowania komputerowego w analizie jakościowego materiału badawczego w postaci pogłębionych wywiadów swobodnych. Celem powyższego fragmentu było jedynie ukazanie aktualnego statusu metod i technik jakościowych oraz pobieżne wskazanie ich zalet, które miały wpływ na wybór podejścia jakościowego do badania łódzkich gated communities ${ }^{3}$.

${ }^{2} \mathrm{~W}$ tym miejscu warto zauważyć, że obok triangulacji metodologicznej w literaturze przedmiotu wyróżnia się także triangulację danych, badaczy i triangulację teoretyczną (Konecki 2000: 86).

${ }^{3}$ Próby zdefiniowania osiedli typu gated communities, a nawet samo przetłumaczenie tego terminu na język polski nie jest łatwe. Jak słusznie zauważa Jacek Gądecki (2007), w literaturze istnieje wiele rodzajów definicji - od mniej lub bardziej restrykcyjnych aż po bardzo liberalne. W swojej monografii poświęconej tylko temu zjawisku Edward Blakely i Mary Snyder (1997) zaznaczają, że nie piszą o „wielorodzinnym, zwartym typie zabudowy, kondominiach z systemem zabezpieczeń i portierami”, raczej interesują się osiedlami „których mury i płoty wykluczają publiczny dostęp do ulic, chodników, parków, plaż, rzek i placów zabaw [...] wszystkich zasobów, które bez tych bram i murów byłyby otwarte i używane przez wszystkich obywateli". Powyższą definicję na pewno należałoby uznać za restrykcyjną, co więcej - w warunkach polskich trudno byłoby znaleźć osiedla, które w podobny sposób, jak te amerykańskie, ograniczają dostęp do przestrzeni publicznych. W związku z powyższym za Bohdanem Jałowieckim oraz Markiem S. Szczepańskim (2006) można przyjąć, że gated coomunities to inaczej „społeczności za bramą”, czyli wyselekcjonowane populacje, które zamieszkują ogrodzone i strzeżone osiedla. W tym przypadku głównym kryterium uznania danego obszaru za gated communities może być istniejące ogrodzenie oraz pozostałe elementy uniemożliwiające obcym wejście na teren osiedla, m.in. monitoring, stała 


\section{Metodologia badania i wykorzystywane techniki badawcze}

W kontekście wspomnianych powyżej badań, będących tłem niniejszego artykułu, zdecydowano się zastosować jakościową analizę fotografii wykonanych przez badacza oraz pogłębione wywiady swobodne także z wykorzystaniem fotografii. W dalszej części artykułu, zgodnie z założonym celem, szczegółowo zostanie omówiony sposób analizy zebranego materiału w ramach przeprowadzonych wywiadów. W tym miejscu warto jednak nieco przybliżyć technikę wykorzystywaną w badaniu. W literaturze przedmiotu wywiad jakościowy (qualitive interview) definiuje się jako „[...] wywiad prowadzony przez moderatora, w formie swobodnej dyskusji z respondentem, za pomocą niestandaryzowanych narzędzi badawczych (scenariusza wywiadu)" (Słownik badawczy)4.

W innej definicji podkreśla się, że jest to jakościowa technika uzyskiwania danych, która opiera się na bezpośredniej komunikacji o zróżnicowanym stopniu standaryzacji, przybierająca formę mniej lub bardziej ukierunkowanego dialogu, w którym rola prowadzącego (badacza) polega głównie na słuchaniu respondenta (Niedbalski 2012). Z kolei zdaniem Babbiego (2007) wywiad swobodny to nic innego jak rozmowa, której prowadzący nadaje pewien kierunek i kładzie nacisk na pewne tematy. Jego zdaniem w idealnej sytuacji wypowiedzi badanego powinny stanowić zdecydowaną większość rozmowy, natomiast wypowiedzi badacza powinny się ograniczać do $5 \%$ czasu całej konwersacji (Babbie 2007). Natomiast zdaniem Kvale (2010) wywiad jakościowy to narzędzie umożliwiające badaczowi poznanie, w jaki sposób jednostki doświadczają swojego świata i jak go postrzegają. Dzięki tej technice badacz zyskuje wgląd w świat życia swoich rozmówców, którzy własnymi słowami opisują swoje działania, doświadczenia i poglądy (Kvale 2010). Kvale w następujący sposób rozpoczyna jeden z pierwszych rozdziałów swojej książki w całości poświęconej prowadzeniu wywiadów:

Jeżeli chcesz dowiedzieć się, w jaki sposób ludzie rozumieją swój świat i swoje życie, to dlaczego z nimi o tym nie porozmawiasz? Rozmowa jest podstawową formą interakcji międzyludzkiej. Ludzie rozmawiają ze sobą, wchodzą w interakcje, zadają pytania i udzielają odpowiedzi. Dzięki rozmowie poznajemy innych, ich doświadczenia, uczucia, nadzieje i świat, w którym żyją. Przeprowadzając wywiad, badacz pyta i słuch tego, co ludzie sami mają do powiedzenia o swoim świecie życia, na temat swoich marzeń, lęków i pragnień, słyszy wyrażane przez nich poglądy i opinie ujęte w ich własne słowa, poznaje ich sytuację w szkole i pracy, ich rodzinę oraz życie społeczne (Kvale 2010: 28).

ochrona. Wspomniane powyżej kryteria definicyjne stanowiły podstawę wyboru poszczególnych osiedli i mieszkańców do badania. Każdy z respondentów był mieszkańcem osiedla, które posiadało przynajmniej zewnętrzne ogrodzenie, a dodatkowo także pozostałe elementy uniemożliwiające wtargnięcie obcym na teren wspólnoty.

${ }^{4}$ http://dobrebadania.pl/slownik-badawczy.html?b=baza\&szczegolowo=155 [dostęp: 26.04 .2014 ]. 
Chęć wyeliminowania pewnej sztuczności, nieufności między badanym a badaczem oraz wspomniane przez Kvale cechy wywiadu sprawiły, że do przeprowadzenia badania na temat gated communities zdecydowano się wykorzystać technikę pogłębionego wywiadu swobodnego. Przedmiotem badania były osoby zamieszkujące tzw. osiedla zamknięte, natomiast problematyka badawcza koncentrowała się wokół motywów i przyczyn wyboru gated communities na miejsce zamieszkania, dostrzeganych przez mieszkańców zalet i wad tego typu kompleksów, a także wewnętrznych relacji społecznych w nich panujących.

Jacek Gądecki (2007) przedstawia dwie główne przyczyny powstawania osiedli typu gated communities. Jego zdaniem te dwa sposoby wyjaśnienia tego fenomenu, przez niektórych traktowane jako konkurujące ze sobą, faktycznie się uzupełniają. W pierwszym przypadku przyczyn powstania tych osiedli upatruje się w lęku i strachu oraz łączy głównie z latami 70. i 80. w Stanach Zjednoczonych. Druga koncepcja kładzie nacisk na zmianę klasową i wiążącą się z nią potrzebę prestiżu. Osiedla tego typu są następną utopią klasy średniej, po homogenicznych przedmieściach (Gądecki 2007: 91). Powyższe wyjaśnienia odnoszą się bezpośrednio do sytuacji w Stanach Zjednoczonych, natomiast w ramach opisywanego badania celem było ustalenie, z jakiej przyczyny mieszkańcy Łodzi wybierają tego typu kompleksy na swoje nowe miejsca zamieszkania. Zainteresowanie swego rodzaju waloryzacją (wady-zalety) życia w gated communities wynikało z kolei z wcześniej przeprowadzonego zwiadu badawczego, z którego wynikało, że oprócz zdecydowanie atrakcyjniejszych przestrzeni i komfortu, mieszkanie na osiedlach zamkniętych wiąże się ze znacznymi ograniczeniami wynikającymi z restrykcyjnych regulaminów osiedlowych. W związku z powyższym chciano zweryfikować, jakie wady i zalety nowych osiedli dostrzegają ich mieszkańcy. Z kolei trzeci problem związany był z poruszaną przez amerykańskich badaczy kwestią ustalenia, ile jest wspólnotowości w „społecznościach za bramą” (Blakely, Snyder 1997).

Zważywszy na poruszaną problematykę i jej drażliwość, technika pogłębionego wywiadu swobodnego wydawała się najwłaściwszym wyborem. Ponadto ze względu na możliwą niechęć badanych do przedstawienia swoich własnych motywów wyboru osiedla zamkniętego ${ }^{5}$ oraz wskazania dostrzegalnych wad do wywiadu włączono również część wizualną, tzn. badanym pokazywano kilkanaście

\footnotetext{
${ }^{5}$ Przyjęto założenie, że badani niechętnie będą przyznawać się, że przyczyną wyboru osiedla zamkniętego był prestiż i chęć wyróżnienia się w stosunku do osób, które nie mogę pozwolić sobie na zamieszkiwanie w tego typu miejscach. Ponadto zakładano, że badani raczej niechętnie będą opowiadać o potencjalnych wadach osiedla, do którego niedawno się przeprowadzili i za które zapłacili dość wysoką cenę. W związku z powyższym zdecydowano się na swego rodzaju projekcję polegającą na założeniu, że badani, analizując przedstawiane zdjęcia, będą również odnosić się do siebie i osiedli, na których mieszkają.
} 
zdjęć przedstawiających łódzkie osiedla zamknięte i proszono o komentarz: kto może w nich mieszkać i dlaczego? jak mogą wyglądać relacje między sąsiadami? jakie można dostrzec zalety i wady takich osiedli? Dopiero po omówieniu zaprezentowanego zbioru zdjęć badacz rozpoczynał rozmowę na temat sytuacji respondenta, czyli jego motywów wyboru gated communities, wad i zalet osiedla, na którym mieszka oraz jego relacji z sąsiadami. Jednocześnie zakładano, że odniesienia do indywidualnej sytuacji pojawią się już w trakcie wizualnej części wywiadu, np. badani będą porównywać swoje osiedle do tych przedstawianych na zdjęciach.

W efekcie za Krzysztofem Kosełą (1989) można uznać, że w badaniach nad łódzkimi gated communities wykorzystano technikę wywiadu z interpretacją fotogramów. Wydaje się, że technika ta w jeszcze większym stopniu niweluje pewną sztuczność sytuacji badawczej niż tradycyjny wywiad swobodny. W przypadku tego drugiego bodźcem wywołującym wypowiedź respondenta są pytania, natomiast w pierwszym - zdjęcie (fotogram). W związku z powyższym rozmówcy (badanemu) może wydawać się, że badanie dotyczy w głównym stopniu prezentowanych obrazów, a on sam przyjmuje rolę tzw. trzeciego, czyli postrzega siebie jako współpracownika badacza (Collier 1986, za: Olechnicki 2003).

W metodologii wielokrotnie zwracano i nadal zwraca się uwagę na możliwość wypaczenia wyniku badań poprzez zadawanie pytań sugerujących. Gdy jako bodziec stosuje się zdjęcie, takie zagrożenie prawie całkowicie zostaje wyeliminowane. Koseła (1989) metaforycznie pisze, że fotografia jest swego rodzaju „wytrychem”, który otwiera wszystkie drzwi, nawet te niechciane, powodując "lawinę" skojarzeń. Sprowokowanie takiej „lawiny” jest jednocześnie zaletą i wadą. Zazwyczaj badaczom zależy na bogatym materiale badawczym, ale w tym przypadku może się okazać, że materiału jest tak dużo i jest on tak różnorodny, że badacz nie jest w stanie sobie z nim poradzić (Koseła 1989). Jednakże w przypadku omawianych badań zagrożenie to zostało w pewnym stopniu wyeliminowane poprzez opracowanie szczegółowych dyspozycji z listą poszukiwanych informacji, które ankieter miał uzyskać podczas omawiania każdego zdjęcia. Natomiast samo opisywanie i analizowanie zdjęć miało sprowokować badanego do większej szczerości. W tym kontekście za przykład może posłużyć opisywana przez Olechnickiego (2003) relacja z przebiegu wywiadu fotograficznego Collierów z księdzem, który początkowo wypowiadał się w sposób bardzo sztywny, chwaląc i podkreślając tradycyjne wartości swojej wspólnoty, lecz gdy zobaczył zdjęcie znanej mu zamężnej kobiety spoufalającej się z innym mężczyzną poczerwieniał i wybuchł gniewem. Po tym wybuchu gniewu i uspokojeniu się księdza wywiad przybrał zupełnie inną formę, wersję oficjalną zastąpiła nieoficjalna. Licząc na podobny efekt w przypadku omawianych badań, zdecydowano się na wykorzystanie kilku zdjęć, które wcześniej zostały wykonane przez badacza w ramach zwiadu terenowego. 
Wywiady z mieszkańcami łódzkich osiedli zamkniętych zostały przeprowadzone w dwóch okresach, a mianowicie w roku 2008 oraz 2012. Należy zauważyć, że nie badano tych samych osób i nie weryfikowano ewentualnych zmian w opiniach na temat gated communities. Celem drugiego pomiaru było uzupełnienie i zaktualizowanie materiału empirycznego. W obu przypadkach wykorzystano nielosowy dobór próby w postaci kuli śnieżnej, co wynikało m.in. z trudności w dotarciu do respondentów. Natomiast jedynym kryterium doboru do badania było zamieszkiwanie na osiedlu zamkniętym ${ }^{6}$, które musiało znajdować się w granicach administracyjnych miasta Łodzi. Każdy z wywiadów był rejestrowany za pomocą dyktafonu.

\section{Analizowanie zebranego materiału badawczego}

Materiał zebrany w roku 2008 był analizowany za pomocą tradycyjnej techniki wykorzystującej papier i ołówek. Przed rozpoczęciem analizy przygotowano szczegółowe transkrypcje z przeprowadzonych wywiadów. Każdemu wywiadowi oraz każdej transkrypcji przypisano odpowiedni numer identyfikacyjny. Następnie każdą transkrypcję wydrukowano w dwóch egzemplarzach i poddano analizie poprzedzonej kodowaniem. W literaturze przedmiotu jednym z popularniejszych sposobów analizy materiałów jakościowych jest podejście wypracowane w ramach metodologii teorii ugruntowanej, w ramach której wyróżnić można dwa rodzaje kodowania, a mianowicie rzeczowe i teoretyczne (Konecki 2000: 51):

Kodowanie rzeczowe odnosi się do rzeczowego skonceptualizowania danego obszaru badań, czyli nadania nazw lub przepisywania pojęć zebranemu materiałowi empirycznemu opisującemu daną rzeczywistość. Natomiast kodowanie teoretyczne dotyczy konceptualizacji wzajemnych relacji między poszczególnymi kategoriami tj. budowania hipotez.

W ramach kodowania rzeczowego wyróżnia się jeszcze kodowanie otwarte i selektywne. Pierwsze polega na zakodowaniu zebranego materiału na wszystkie możliwe sposoby tzn. przypisaniu poszczególnym wierszom lub paragrafom etykiet, które mają umożliwić oderwanie się od materiału empirycznego i przejście

${ }^{6}$ Dodać należy, że badanymi mogły być tylko osoby, które zamieszkiwały na osiedlach pierwotnie zamkniętych tzn. takich, które ogrodzone były w chwili ich oddania do użytku. W przestrzeniach polskich miast coraz częściej można spotkać się z tzw. wtórnym grodzeniem, tj. wygradzaniem pojedynczych bloków lub ich skupisk. Zjawisko to można m.in. wytłumaczyć pojawianiem się osiedli typu gated communities, które niejako prowokują mieszkańców tradycyjnych bloków do grodzenia, tzn. gdy w okolicy pojawia się nowy budynek mieszkalny, który zostaje wygrodzony, mieszkańcy starszych bloków, podejmują inicjatywę, aby odgrodzić również swój budynek, co w efekcie przyczynia się do znacznego „szatkowania” i prywatyzowania przestrzeni miasta. 
na poziom konceptualny. Następnie badacz powinien zdecydować, które kategorie powinny zostać dalej opracowywane poprzez tzw. nasycanie ich własnościami. Wybór kategorii determinowany jest zainteresowaniami badacza oraz rodzajem danych. Kolejnym krokiem, po wyborze kategorii, jest tzw. kodowanie selektywne, czyli ograniczenie kodowania do tych zmiennych, które odnoszą się do interesującej nas kategorii (Konecki 2000).

Powyższe podejście ma wiele zalet - należy wspomnieć przede wszystkim o wyeliminowaniu ryzyka polegającego na usilnym poszukiwaniu w materiale badawczym potwierdzenia wcześniej przyjętych założeń teoretycznych (zasada polegająca na maksymalnym ograniczeniu konceptualizacji) (zob. Konecki 2012). Niemniej w odniesieniu do badań nad łódzkimi gated communities, mimo pewnych inspiracji wyniesionych z metodologii teorii ugruntowanej, materiał empiryczny był analizowany w inny sposób, co wynikało m.in. z wcześniejszej konceptualizacji, z precyzyjnie opracowanych celów badawczych, a mianowicie ustalenia przyczyn wyboru osiedli zamkniętych na miejsce zamieszkania, kształtujących się $w$ nich relacji sąsiedzkich oraz dostrzegalnych przez mieszkańców wad i zalet. W związku z powyższym pierwszym etapem analizy było znalezienie i zakodowanie fragmentów dotyczących powyższych obszarów. Badacz nadawał następujące kody: motywy/przyczyny, wady, zalety, wspólnotowość i więzi. Ponadto wywiad składał się z dwóch części: wizualnej dotyczącej potencjalnych mieszkańców (opinii badanych o mieszkańcach gated communities) oraz indywidualnej sytuacji badanego, znalazło to więc odzwierciedlenie w przypisywanych kodach, co prezentuje tab. 1.

Tabela 1. Wstępne kody w badaniu łódzkich gated communities

\begin{tabular}{|l|l|}
\hline \multicolumn{2}{|c|}{ WSTĘPNE KODY } \\
\hline $\begin{array}{c}\text { Potencjalni mieszkańcy gated communities } \\
\text { (ogólne opinie badanego) }\end{array}$ & \multicolumn{1}{|c|}{ Indywidualna sytuacja badanego } \\
\hline - motywy/przyczyny & - motywy/przyczyny \\
- wspólnotowość i więzi & - wspólnotowość i więzi \\
- wady & - wady \\
- zalety & - zalety \\
\hline
\end{tabular}

Źródło: opracowanie własne.

W tym przypadku nie można mówić o wykorzystaniu metodologii teorii ugruntowanej, gdyż przed rozpoczęciem fazy terenowej przeprowadzono szczegółową konceptualizację, co miało swoje odzwierciedlenie w sposobie prowadzenia wywiadów, a w dalszej kolejności w analizie zebranego materiału, w którym doszukiwano się interesujących, ze względu na przedmiot i cele badania, wątków. 
W dalszej kolejności wybrane fragmenty dotyczące motywów, wspólnotowości, wad i zalet poddano kolejnemu kodowaniu. W tym przypadku można mówić o swego rodzaju połączeniu kodowania otwartego i selektywnego, gdyż z jednej strony badacz starał się zakodować wybrane wcześniej fragmenty na wszystkie możliwe sposoby, natomiast z drugiej - należy podkreślić, że kodowanie ograniczało się do wcześniej wybranych i wyselekcjonowanych kategorii przedstawionych w tab. 1, czyli można stwierdzić, że w fazie analizy wykorzystano wybrane elementy metodologii teorii ugruntowanej, ale nie trzymano się ich w sposób opisywany i zalecany przez jej twórców i zwolenników.

Sam proces był żmudną i czasochłonną pracą. Na pierwszym etapie każdy wywiad został kilkakrotnie przeczytany przez badacza, następnym krokiem było zaznaczenie odpowiednich fragmentów za pomocą jednego ze wstępnych kodów. Dany fragment kodowano jednocześnie na dwóch egzemplarzach transkrypcji. Następnie jeden z egzemplarzy został pocięty, a jego części poselekcjonowane zgodnie z przyjętą wcześniej listą wstępnych kodów. Procedurę powtórzono w odniesieniu do wszystkich zebranych wywiadów. W sumie otrzymano osiem grup wyciętych fragmentów, które treściowo odpowiadały kodom przedstawionym w tab. 1. Co więcej, każdemu wyciętemu fragmentowi wywiadu nadawano numer identyfikacyjny zgodny z numerem przypisanym danemu wywiadowi. Tak uporządkowane fragmenty zostały następnie poddane szczegółowemu kodowaniu. Każdy wywiad został przygotowany i zakodowany w dwóch wersjach, aby w trakcie szczegółowej analizy, podczas pracy nad powycinanymi fragmentami, badacz miał możliwość powrotu do całego wywiadu i zweryfikowania kontekstu danej wypowiedzi.

Przedstawiona powyżej procedura zostałaby powtórzona po zebraniu materiału w roku 2012, aczkolwiek ze względu na możliwość skorzystania z programu komputerowego QDA Miner zarówno materiał zebrany w roku 2008, jak i w 2012 został ponownie poddany analizie przy wykorzystaniu wspomagania komputerowego. W dalszej części artykułu zostaną przedstawione możliwości przeprowadzenia jakościowej analizy przy pomocy ww. oprogramowania. Warto wspomnieć, że w literaturze przedmiotu wymienia się dwa rodzaje publikacji dotyczących programów komputerowych wspierających analizę jakościową (Brosz 2012). Pierwszy rodzaj opracowań koncentruje się na opisie i analizie wpływu narzędzi komputerowych na proces badawczy, z kolei drugą grupę tekstów stanowią publikacje instruktażowe. Jak dodaje Brosz, artykuły tego drugiego rodzaju dość szybko się dezaktualizują z powodu szybkiego postępu technologicznego. Niniejszy artykuł w większym stopniu wpisuje się w drugi rodzaj opracowań wymienionych przez Brosza, aczkolwiek próbowano również przedstawić wpływ programu na przebieg samego procesu badawczego. Ponadto w odniesieniu do części instruktażowej należy zaznaczyć, że przedstawiono w niej jedynie 
podstawowe aspekty pracy w programie QDA Miner ${ }^{7}$, co z jednej strony można rozpatrywać jako mankament, natomiast $z$ drugiej - można mieć nadzieję, że nie ulegnie on szybkiej dezaktualizacji. Zauważyć należy, że producenci tego typu oprogramowania w każdej nowej aktualizacji dodają nowe funkcje, natomiast sporadycznie rewolucjonizują podstawowe elementy programu i jego funkcje.

\section{Rozpoczynanie pracy w programie QDA Miner}

Pierwszą czynnością przed przystąpieniem do zasadniczej pracy jest utworzenie nowego projektu oraz importowanie danych, które będziemy poddawać analizie, w tym przypadku transkrypcji wywiadów z mieszkańcami osiedli zamkniętych. Po uruchomieniu programu pojawi się okno startowe z trzema opcjami do wyboru. Zaczynając pracę po raz pierwszy, wybieramy pierwszą opcję Create a new project. Nowy projekt można utworzyć również poprzez wybranie opcji New z głównego menu Project, znajdującego się w lewym górnym rogu (ilustr. 1).

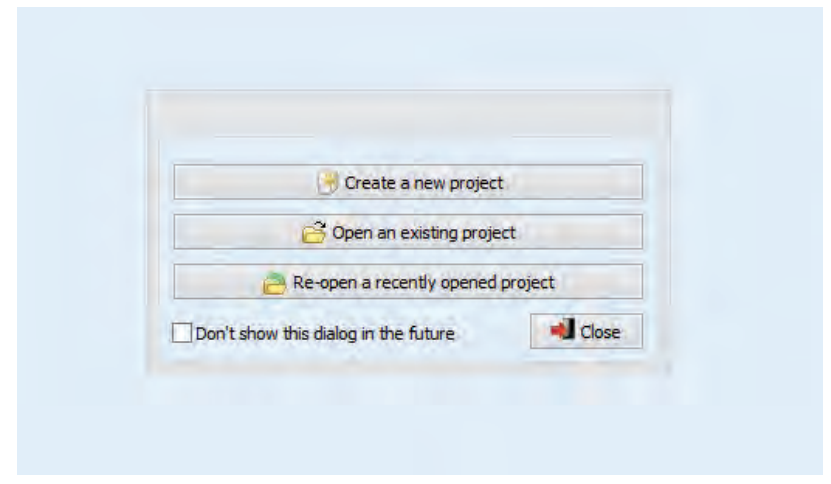

Ilustr. 1. Okno startowe programu QDA Miner

Źródło: opracowanie własne

W dalszej kolejności program zapyta o sposób utworzenia nowego projektu. Istnieje możliwość importowania listy gotowych dokumentów lub obrazów (Create a project from a list of documents/images) z utworzonej wcześniej bazy (Import from an exsiting data file) bądź stworzenia projektu od podstaw (Create a blank project). Jeśli dysponujemy gotowymi transkrypcjami z wywiadów zapisanymi w formie tekstowej, najodpowiedniejszym sposobem jest wybór opcji pierwszej (ilustr. 2).

\footnotetext{
${ }^{7}$ Przygotowując niniejszy artykuł, korzystano z wersji 4.7.1 programu QDA Miner.
} 


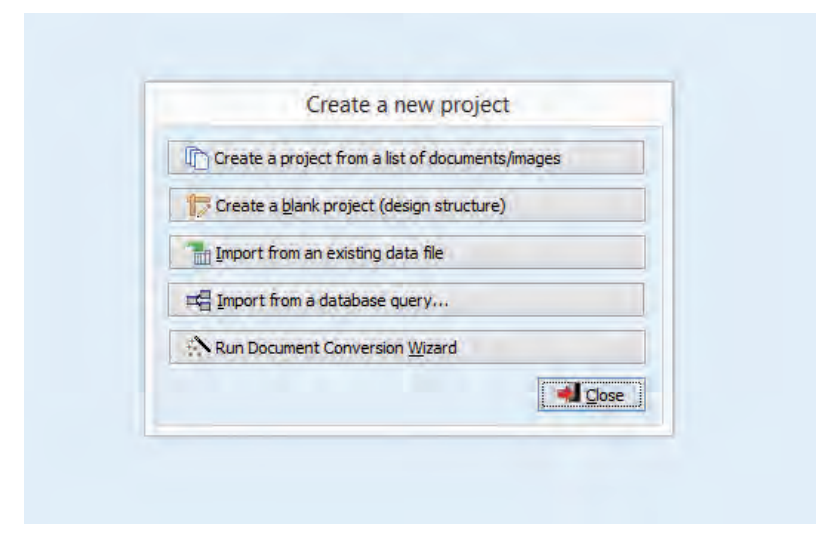

Ilustr. 2. Tworzenie nowego projektu z listy gotowych dokumentów

Źródło: opracowanie własne

Następnie musimy wskazać folder, z którego powinien zostać importowany materiał do analizy. Wybrane dokumenty należy dodawać za pomocą przycisku Add. Po wyselekcjonowaniu wszystkich interesujących nas materiałów tworzymy nowy projekt za pomocą opcji Create znajdującej się na dole okna. Przed utworzeniem nowego projektu warto jednak pamiętać, aby zaznaczyć opcję usuwającą obrazy (Remove images). Ma to szczególne znaczenie w przypadku plików w formacie PDF, gdyż ich waga wraz z obrazami sprawia, że program zdecydowanie wolniej reaguje na nasze komendy (ilustr. 3).

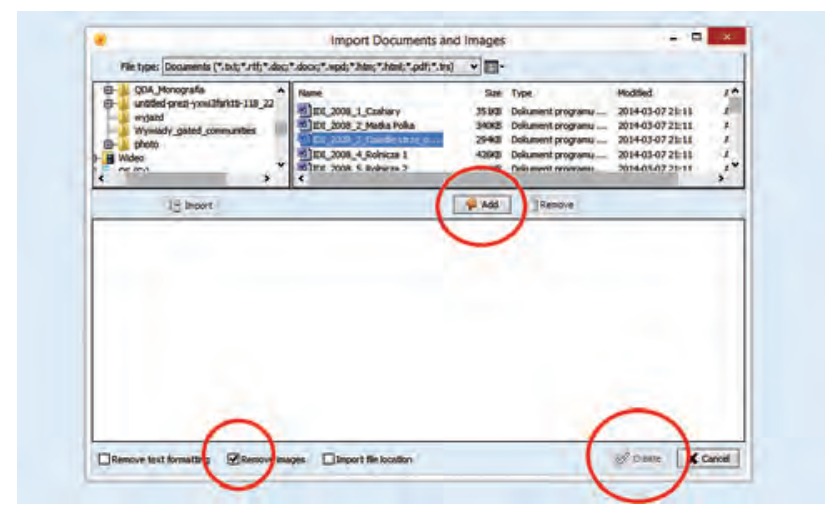

Ilustr. 3. Dodawanie dokumentów do nowego projektu

Źródło: opracowanie własne

Warto zaznaczyć, że większość programów z rodziny CAQDAS może pracować z różnymi plikami w różnych formatach. W programie QDA Miner możemy również analizować dokumenty tekstowe, obrazy, pliki PDF itp. 
Po zaimportowaniu danych $w$ dalszej kolejności ukaże się okno nowo utworzonego projektu umożliwiające rozpoczęcie pracy analitycznej na wyselekcjonowanym przez nas materiale. Przed rozpoczęciem kodowania warto jednak bliżej zapoznać się ze strukturą programu. Sam interfejs jest bardzo intuicyjny i łatwy w obsłudze. Wszystkie opcje dostępne są w górnym pasku. Natomiast okno, w którym będziemy pracować, zostało podzielone na kilka części. Każdy z tych elementów można dowolnie personalizować i dostosowywać do swoich potrzeb, za pomocą myszy bądź touchpada, rozszerzając bądź zwężając poszczególne pola. Przede wszystkim w trakcie kodowania warto powiększyć okno z kodami (CODES), aby wszystkie kody były widoczne. W głównym oknie ukazany jest zaznaczony aktualnie przypadek (CASE), czyli podstawowa jednostka organizacji kodowanego materiału, a w naszym przypadku jedna z zaimportowanych transkrypcji. Wszystkie transkrypcje, które dodaliśmy w trakcie tworzenia nowego projektu, wyświetlane są w górnym lewym oknie zatytułowanym CASES. Warto zauważyć, że w każdym momencie pracy możemy dodawać lub usuwać poszczególne przypadki do analizy. Ponadto program umożliwia filtrowanie oraz grupowanie przypadków za pomocą wartości zmiennych, które je opisują. Wszystkie te opcje dostępne są po wyborze zakładki CASES znajdującej się w górnym pasku zadań bądź po kliknięciu prawym przyciskiem myszy w oknie CASES, znajdującym się z lewej strony tuż pod paskiem zadań. Kolejnym oknem znajdującym się pod listą przypadków są zmienne VARIABLES, czyli cechy lub wartości, które możemy przypisać każdemu z analizowanych przypadków. Zmienne umożliwiają szybką identyfikację poszczególnych przypadków, a także porównywanie ich pod względem istotnych cech z punktu widzenia badania. Każdy z analizowanych przez nas przypadków możemy opisać za pomocą dowolnej liczby zmiennych, w tym celu program oferuje kilka rodzajów zmiennych: nominalnych/porządkowych (nominal/ordinal), numerycznych (numeric), dat (date), zmiennych typu prawda/fałsz (boolean), łańcucha dowolnych znaków (short string), tekstowych (document) i obrazów (image). Każdą ze zmiennych możemy dowolnie nazwać oraz opisać. Ostatnim elementem znajdującym się z lewej strony okna projektowego są kody (CODES), czyli cechy lub wartości, które możemy przypisać danemu fragmentowi analizowanego tekstu. Dany kod możemy przypisywać dowolnej liczbie fragmentów kodowanego tekstu, co więcej - dany fragment tekstu może być zakodowany kilkakrotnie różnym kodem. W przypadku programu QDA Miner kody są porządkowane za pomocą tzw. kategorii (category). Każdy z naszych kodów może zostać dodany tylko i wyłącznie do jednej kategorii. Natomiast w każdej z kategorii może się znaleźć niezliczona liczba kodów. Jak zostało to wspomniane, kategorie służą jedynie do porządkowania struktury kodów, za ich pomocą nie można kodować tekstu. Odnosząc się do badań dotyczących osiedli zamkniętych, przykładową kategorią może być motywacja/przyczyna wyboru gated communities na miejsce 
zamieszkania, z kolei kodami, które mogą się zawierać w ramach tej kategorii, mogą być takie elementy, jak: strach, bezpieczeństwo, prestiż, wygoda i komfort mieszkania, zadbana przestrzeń wewnątrz osiedla etc. (ilustr. 4).

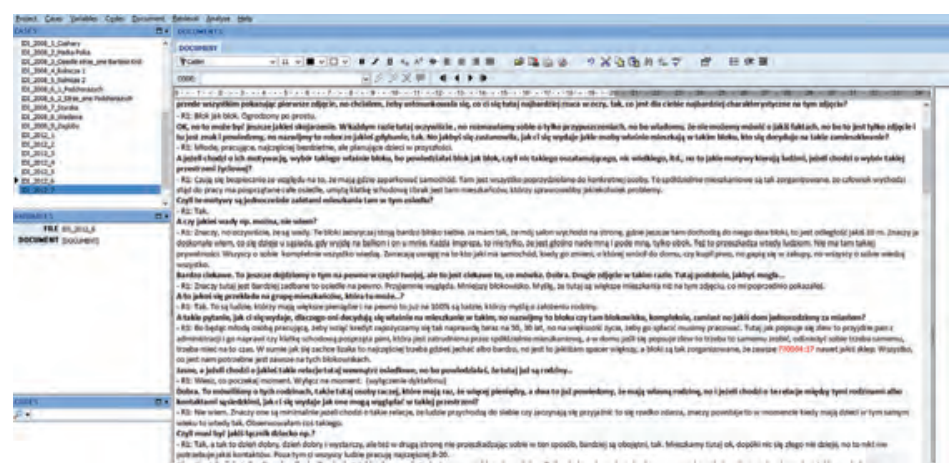

Ilustr. 4. Główne okno programu QDA Miner

Źródło: opracowanie własne

Przedstawione powyżej właściwości i funkcje programu zostaną szczegółowo omówione w dalszej części artykułu.

\section{Opracowanie i przygotowanie zmiennych}

Po zaimportowaniu wybranego do analizy materiału badawczego kolejnym etapem, przed utworzeniem kodów oraz rozpoczęciem przypisywania ich poszczególnym fragmentom tekstu, jest utworzenie zmiennych, które będą opisywać poszczególne jednostki analizy (np. dany wywiad w postaci transkrypcji). Tworzenie zmiennych jest przydatną opcją, gdyż umożliwia porównywanie poszczególnych przypadków z uwzględnieniem wartości danej zmiennej i wybranego kodu, np. tworząc zmienną płeć składającą się z dwóch wartości (kobieta, mężczyzna), możemy porównać, jakie motywy wyboru osiedla zamkniętego podawały kobiety, a jakie mężczyźni i czy motywy te znacznie różnią się od siebie. Innymi słowy, na etapie analizy możemy skrzyżować zmienną z wybranym kodem.

W celu dodania nowej zmiennej należy kliknąć prawym przyciskiem myszy w oknie VARIABLES znajdującym się z lewej strony okna głównego i wybrać opcję add variables, co uruchomi pojawienie się kolejnego okna (Variable Definition) widocznego na ilustr. 5. Następnie niezbędne jest wprowadzenie nazwy zmiennej (Varibable name) jedynie wielkimi literami i bez znaków polskich oraz określenie jej typu (Data type). Możliwe jest również podanie krótkiego opisu danej 
zmiennej (Description), ale ta funkcja jest opcjonalna, a jej zastosowanie zależy od potrzeb badacza. Gdy nasza zmienna jest zmienną nominalną, niezbędne jest również podanie jej wartości. W tym celu wybieramy opcję Edit i wpisujemy każdą z wybranych przez nas wartości w osobnym wierszu. Po dodaniu wszystkich wartości zmiennej klikamy OK, później opcję Add znajdującą się w oknie Variables Definition, a w następnej kolejności wybieramy opcję Create. Nasza nowo utworzona zmienna powinna pojawić się w oknie VARIABLES. Zmienną możemy dodać także poprzez pasek zadań, w tym przypadku również wybieramy opcję Add variables, a dalsze kroki wyglądają analogicznie.

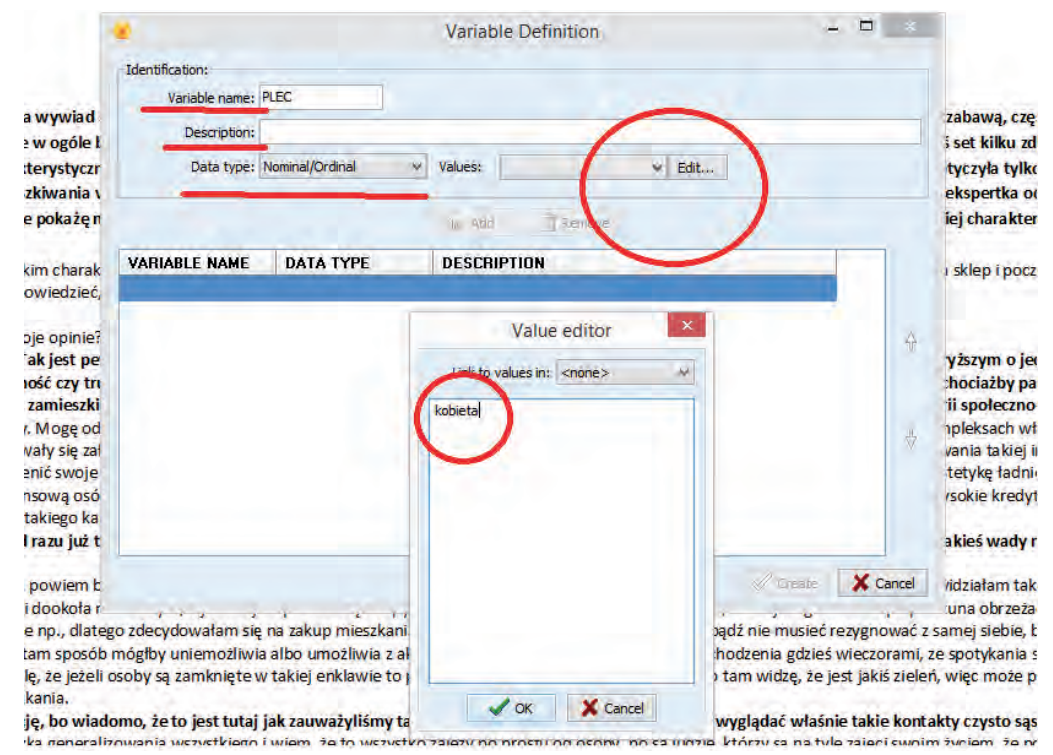

Ilustr. 5. Dodawanie zmiennych

Źródło: opracowanie własne

Do badania łódzkich gated communities zdecydowano się utworzyć następujące zmienne:

1. Płeć: kobieta, mężczyzna (zmienna nominalna),

2. Wykształcenie: wyższe, średnie, zawodowe, podstawowe (zmienna porządkowa),

3. Data przeprowadzenia wywiadu (zmienna data),

4. Liczba lat zamieszkiwania na osiedlu (zmienna numeryczna),

5. Lokalizacja osiedla: centrum, peryferie (zmienna nominalna).

W dalszej kolejności zmienne te wykorzystywano do krzyżowania ich z poszczególnymi kodami. Po utworzeniu wszystkich zmiennych kolejnym elementem przygotowywania bazy jest przypisanie poszczególnym elementom (przypadkom) 
właściwych wartości zmiennych, w tym celu należy najechać kursorem na wartość danej zmiennej, po kliknięciu powinna rozwinąć się lista dostępnych wartości, z których możemy wybrać odpowiednią wartość dla danego przypadku. Czynność tę należy powtórzyć w odniesieniu do wszystkich przypadków wchodzących w skład naszej bazy (ilustr. 6 i 7).

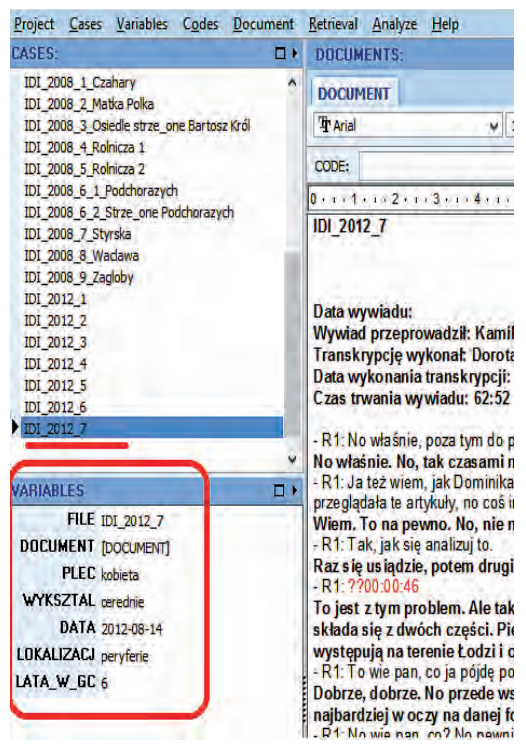

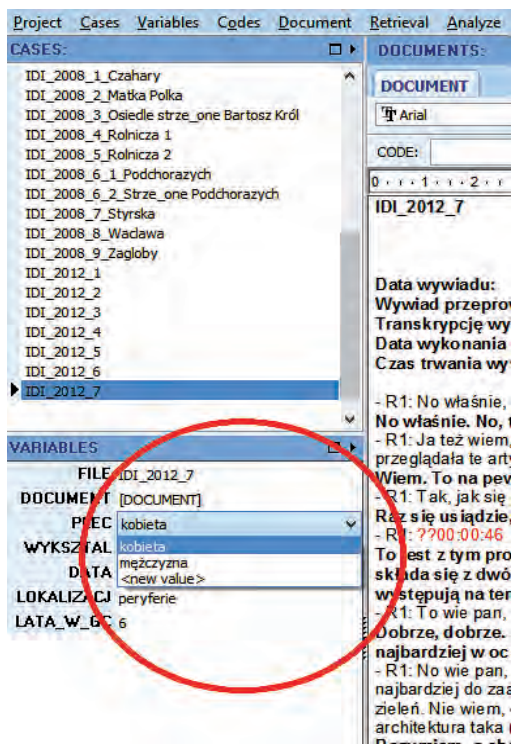

Ilustr. 6. i 7. Przypisywanie wybranych wartości zmiennych wybranym przypadkom

Źródło: opracowanie własne

W każdym momencie analizy możemy dodawać nowe zmienne oraz usuwać lub edytować już istniejące. W tym celu możemy w oknie VARIABLES kliknąć prawym przyciskiem myszy, po czym rozwinie się menu z opcjami (ilustr. 8-11). Podobnie jak w przypadku dodawania zmiennych można również skorzystać z paska zadań poprzez kliknięcie zakładki Variables. W celu usunięcia zbędnej zmiennej wybieramy opcję Delete, po czym wybraną zmienną do wykasowania przenosimy z okna Exsiting variables do okna Variables to delete, a następnie klikamy OK. Z kolei, aby edytować zmienną, należy kliknąć prawym przyciskiem myszy na jej nazwę, a następnie wybrać opcję Edit properties, która umożliwi nam wprowadzenie nowego opisu zmiennej, zmianę jej nazwy, a także dodanie nowych wartości. Możemy wybrać również opcję Transform, która umożliwia zmianę typu zmiennej oraz zrekodowania jej wartości (Recode). 


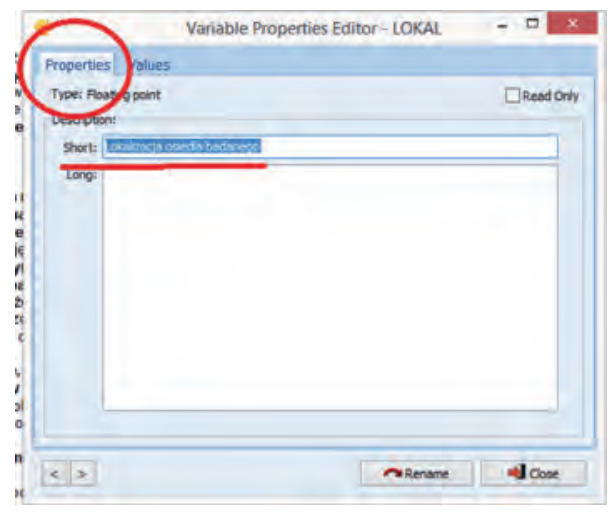

Ilustr. 8. Zmiana nazwy zmiennej

Źródło: opracowanie własne

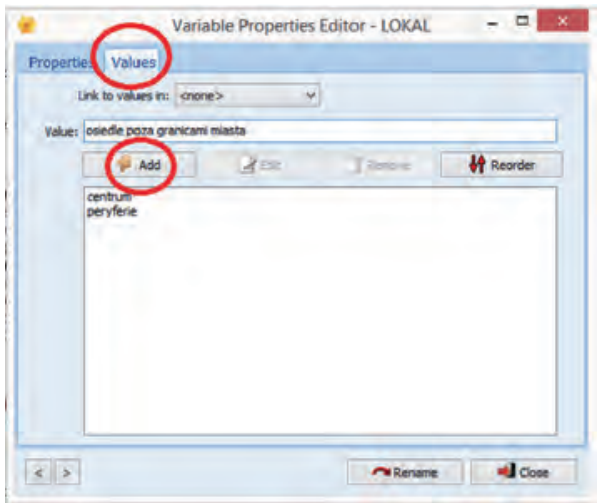

Ilustr. 9. Zmiana opisu zmiennej

Źródło: opracowanie własne

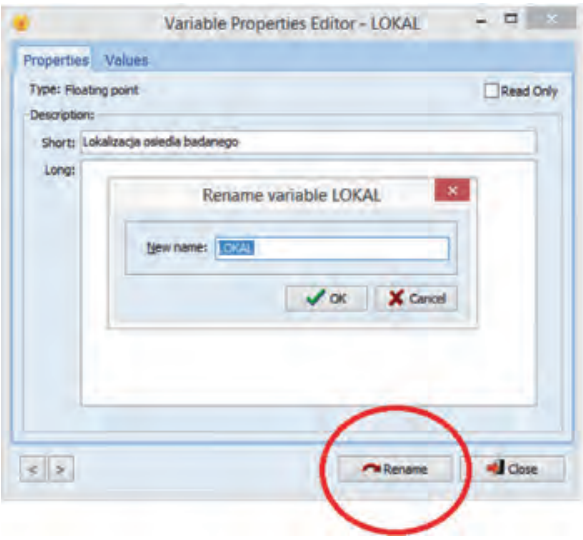

Ilustr. 10. Dodawanie nowej wartości zmiennej Źródło: opracowanie własne 


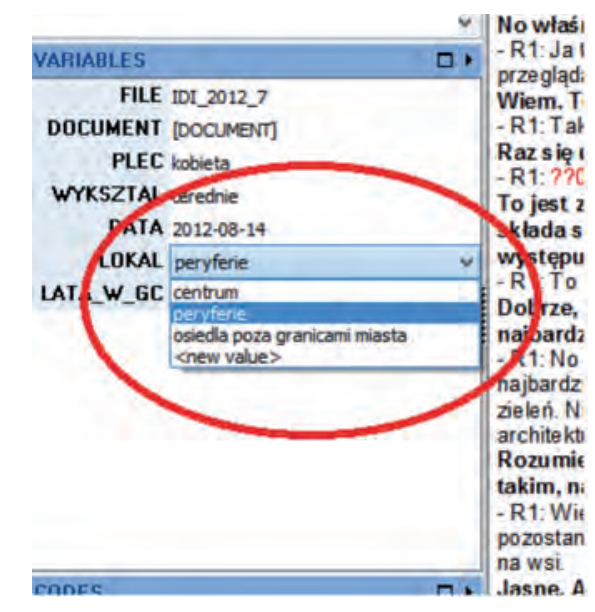

Ilustr. 11. Nowo utworzona wartość zmiennej

Źródło: opracowanie własne

Dodatkową funkcją jest możliwość porządkowania listy zmiennych. Aby z niej skorzystać, należy wybrać opcję Reorder z paska zadań z zakładki Variables lub kliknąć prawym przyciskiem myszy w oknie, w którym wyświetlane są wszystkie utworzone przez nas do tej pory zmienne (VARIABLES). Po wybraniu funkcji Reorder zostanie otwarte okno, w którym należy wybrać daną zmienną oraz za pomocą strzałek przesunąć ją w górę lub w dół, w zależności od naszych preferencji co do kolejności poszczególnych zmiennych. Ponadto w zakładce Variables znajduje się jeszcze opcja Statistics umożliwiająca weryfikację częstości występowania poszczególnych wartości zmiennych (Frequency), a także skrzyżowania dwóch zmiennych (Crosstabs) oraz przedstawienia wyników w postaci graficznej (ilustr. 12-14).
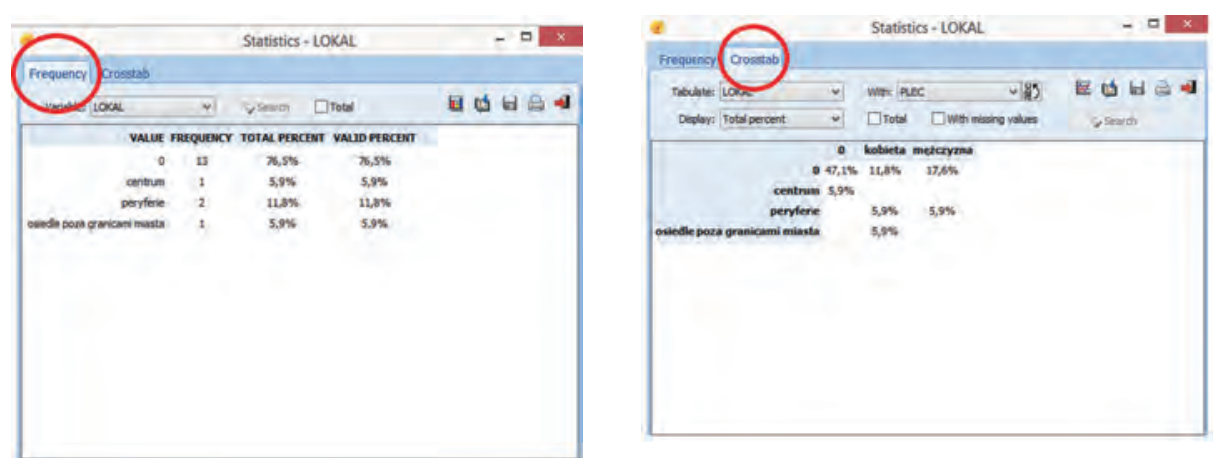

Ilustr. 12. i 13. Częstości występowania wartości danej zmiennej oraz krzyżowanie zmiennych Źródło: opracowanie własne 


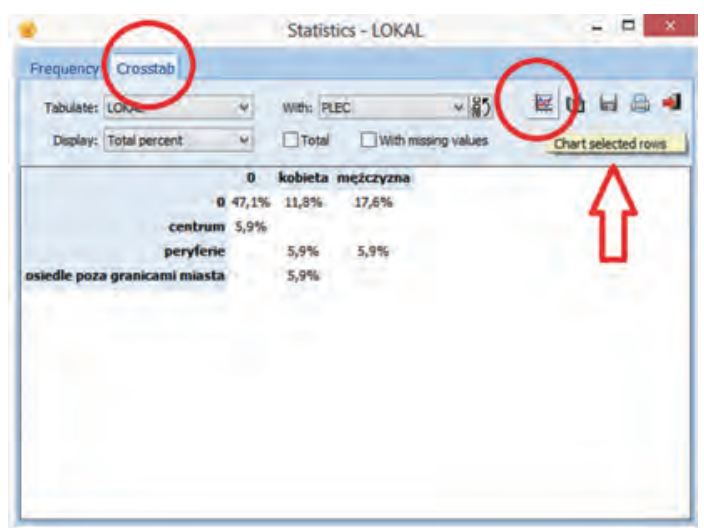

Ilustr. 14. Prezentacja wyników w formie graficznej

Źródło: opracowanie własne

\section{Dodawanie i edytowanie kodów}

Po utworzeniu i opisaniu zmiennych kolejnym etapem jest utworzenie kodów oraz ich ustrukturyzowanie. Podobnie jak w przypadku zmiennych, aby dodać kod, możemy skorzystać z głównego paska zadań, wybierając opcję Codes, a następnie Add lub klikając prawym przyciskiem myszy w oknie znajdującym się w dolnym, lewym rogu strony, zatytułowanym CODES. W oknie, które się pojawi (Code definition), po wyborze funkcji Add, wpisujemy nazwę kodu (Code name) oraz nazwę kategorii (Under), pod którą się znajdzie (ilustr. 15). Warto dodać, że materiał badawczy jest kodowany za pomocą kodów, a nie kategorii, co oznacza, że przy zakodowanym fragmencie tekstu wyświetlać się będzie nazwa kodu, a nie kategorii, warto o tym pamiętać, tworząc strukturę kodową, aby uniknąć sytuacji, w której nazwa kodu będzie niejasna albo nazwa kategorii będzie zbyt szczegółowa. Przykładowo w trakcie analizy wywiadów z mieszkańcami gated communities utworzono kategorię: motywy/przyczyny, a w jej ramach m.in. następujące kody: strach, prestiż, inne. Ponadto możemy wybrać kolor kodu (Color), a także dodać krótki opis (Description), np. instrukcję dla koderów lub przykładowy fragment tekstu, który mógłby zostać zakodowany za pomocą danego kodu. Istnieje również możliwość wskazania kilku słów kluczowych (ilustr. 16). Funkcje te mogą okazać się pomocne w przypadku dużych partii materiału, w sytuacji gdy niezbędna jest praca kilku koderów pracujących równocześnie. Szczegółowa instrukcja oraz słowa kluczowe mogą zminimalizować ryzyko, że różne kody zostaną przypisane do podobnych fragmentów. 


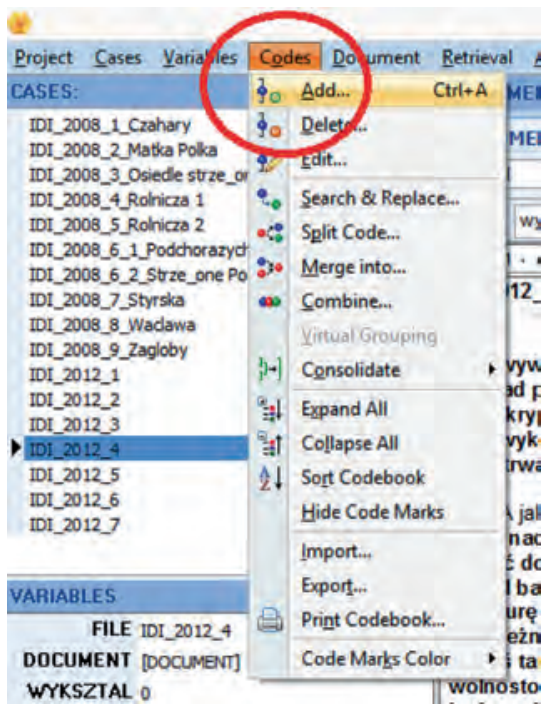

Ilustr. 15. Dodawanie nowego kodu

Źródło: opracowanie własne

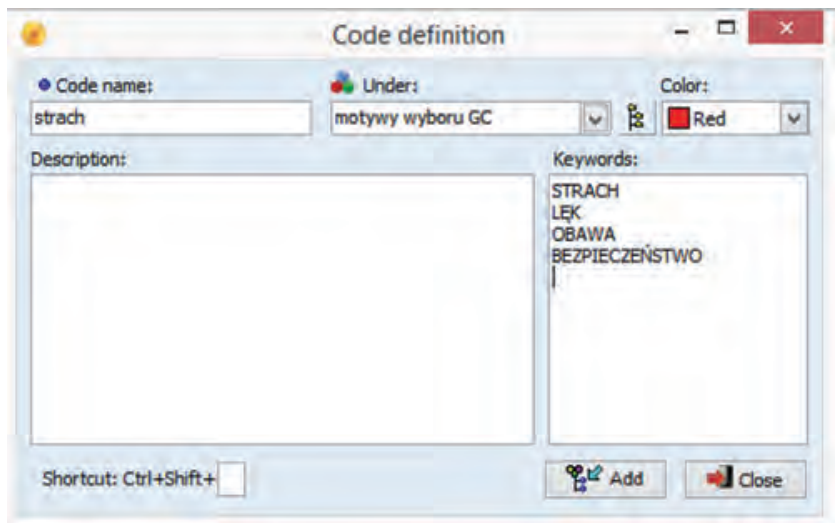

Ilustr. 16. Dodawanie nowego kodu - określanie nazwy oraz słów kluczowych

Źródło: opracowanie własne

Warto również dodać, że program, oprócz tworzenia struktury składającej się z kategorii i kodów, umożliwia również opracowanie podkategorii. W tym celu należy skorzystać z opcji drzewa kodowego (select under which category the new category will be stored), znajdującej się w oknie Code definition między nazwą kategorii a opcją wyboru koloru danego kodu. Chcąc dodać kod, który będzie zawierał się w nowej podkategorii w ramach jednej z już istniejących kategorii, wpisujemy najpierw nazwę kodu (Code name), następnie nazwę podkategorii 
(Under), a w dalszej kolejności za pomocą opcji (select under which category the new category will be stored) wybieramy kategorię, pod którą chcemy umieścić nową podkategorię oraz nowy kod. W przypadku badań nad osiedlami zamkniętymi jedną z kategorii, jaka była wykorzystywana w trakcie analizy, były „wady gated communities", w jej ramach utworzono natomiast podkategorię „,konflikty" - ilustr. 17 przedstawia sposób utworzenia tej podkategorii.

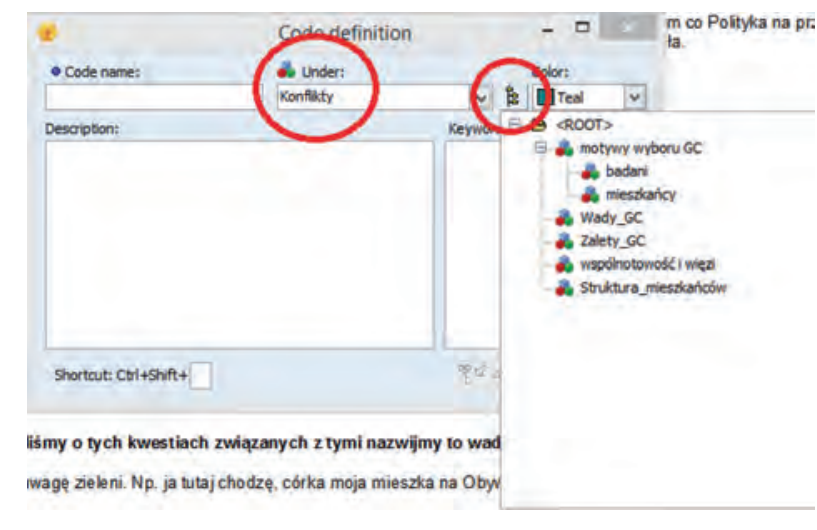

Ilustr. 17. Dodawanie nowego kodu - tworzenie podkategorii

Źródło: opracowanie własne

Warto zauważyć, że podkategorie funkcjonują w programie na analogicznych zasadach jak kategorie, tzn. porządkują strukturę kodów, ale nie można za ich pomocą kodować zebranego materiału.

Usuwanie i edytowanie kodów oraz kategorii jest analogiczne jak w przypadku usuwania i edytowania zmiennych. W tym celu możemy skorzystać z paska zadań, wybierając opcję CODES, a następnie Delete lub Edit code, lub skorzystać z okna kodów (CODES) znajdującego się w dolnym, lewym rogu w oknie całego programu. $W$ drugim przypadku należy najechać kursorem myszy na kod, który chcemy usunąć lub edytować, później kliknąć prawym przyciskiem myszy i wybrać stosowne polecenia, a na koniec je zaakceptować. Program umożliwia również przesuwanie kodów między poszczególnymi kategoriami. Jeżeli chcemy zmienić miejsce danego kodu w strukturze, najłatwiejszym sposobem jest przeciągnięcie go za pomocą myszy z jednej kategorii do drugiej. Opcji tej nie możemy jednak wykorzystać w przypadku kategorii. Przesunięcie jednej kategorii do drugiej nie spowoduje, że ta pierwsza stanie się automatycznie jej podkategorią, a jedynie kategorią równorzędną. Aby utworzyć podkategorię, należy skorzystać $z$ opisanej powyżej opcji (select under which category the new category will be stored). Ponadto istnieje możliwość łączenia (Merge code) i dzielenia kodów (Split code), a także tworzenia kombinacji kodów (Code combination). Wszystkie te trzy opcje dostępne są w pasku zadań bądź w oknie CODES. Warto zauważyć, 
że opcje te są bardzo przydatne w trakcie analizy, gdy okaże się, że część naszych kodów jest zbyt wąska i należałoby utworzyć z nich jeden nowy kod bądź odwrotnie, gdy okaże się, że nasz kod jest treściowo zbyt szeroki i można utworzyć z niego kilka niezależnych kodów. W przypadku drugiej opcji dotychczasowa nazwa kodu, może zostać zamieniona w kategorię, do której będą mogły zostać utworzone nowe kody. W celu przypisania pierwotnie zakodowanych fragmentów do nowo utworzonych kodów, w odniesieniu do każdego z nich program zapyta, do którego nowego kodu należy przypisać dany fragment tekstu.

\section{Kodowanie}

We wcześniejszej części artykułu przedstawiono sposób dodawania i edytowania kodów. W przypadku badań nad łódzkimi osiedlami zamkniętymi wstępną listę kodów utworzono na podstawie przeglądu literatury oraz celów badania. Należy jednak pamiętać, że kody można dodawać na bieżąco, co spełnia również warunki kodowania otwartego w ramach metodologii teorii ugruntowanej.

Samo kodowanie w programie jest proste i bardzo intuicyjne. Wystarczy zaznaczyć dany fragment tekstu za pomocą myszy z wciśniętym klawiszem Shift, a następnie kliknąć dwukrotnie na wybrany kod, który znajduje się w dolnym, lewym oknie (CODES). Istnieje również inna metoda kodowania polegająca na zaznaczeniu wybranego fragmentu tekstu, następnie wybraniu (podświetleniu i kliknięciu) danego kodu z okna znajdującego się w lewym, dolnym rogu, a w dalszej kolejności powrotu do zaznaczonego tekstu i kliknięcia prawego przycisku myszy. Z menu, które się rozwinie, wybieramy opcję Code as... (ilustr. 18).

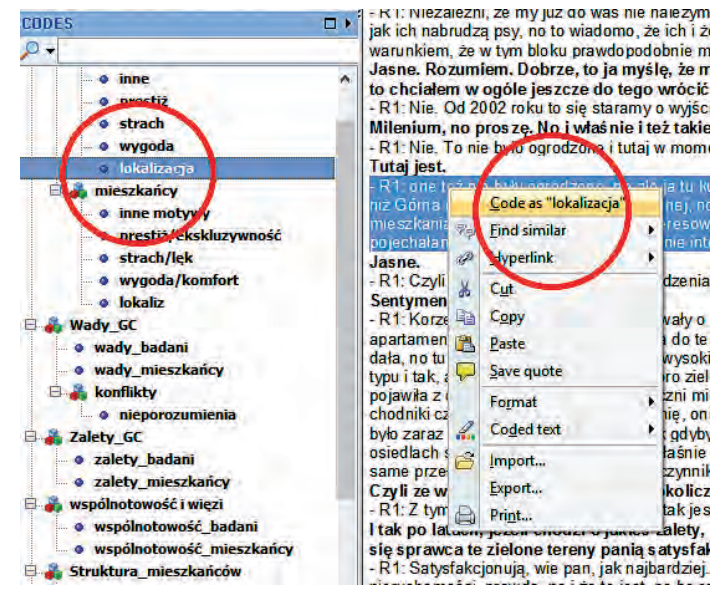

Ilustr. 18. Kodowanie tekstu

Źródło: opracowanie własne 
Po zakodowaniu z prawej strony kodowanego fragmentu powinna wyświetlić się nazwa kodu w kolorze, który dla niego wybraliśmy podczas jego dodawania. Gdy najedziemy kursorem myszy na znajdującą się z boku tekstu nazwę kodu, powinna wyświetlić się nam informacja o miejscu kodu w strukturze kodów (kategoria, podkategoria itp.), dacie kodowania oraz kodującym (ilustr. 19). Dla ułatwienia pracy możemy dodatkowo wyróżnić zakodowany tekst, w tym celu z paska zadań należy wybrać opcję Document, a następnie Coded text i którąś z dostępnych opcji wyróżniania, np. podkreślenie albo zmianę koloru tekstu na kolor symbolizujący kod itp. (ilustr. 20).

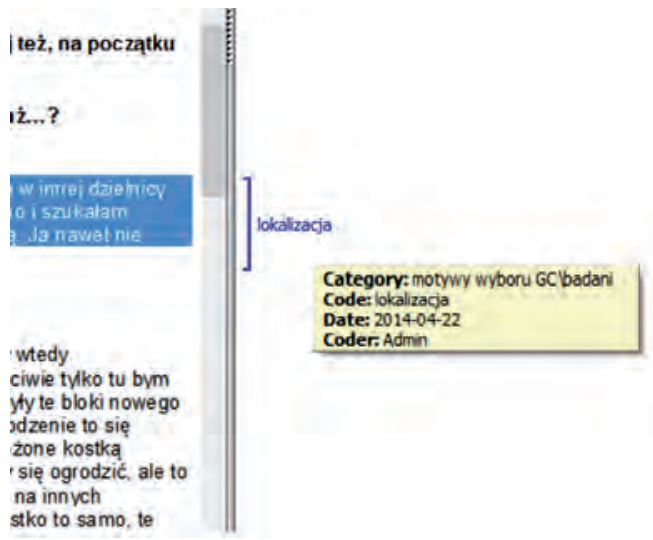

Ilustr. 19. Informacje o kodzie: nazwa kategorii, nazwa kodu, data kodowania, nazwa kodera

Źródło: opracowanie własne

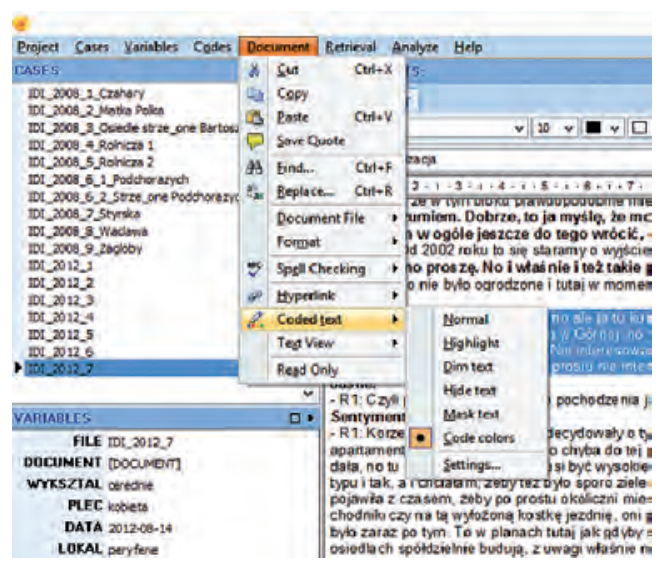

Ilustr. 20. Wyróżnianie danego kodu

Źródło: opracowanie własne 
Program QDA Miner umożliwia również szybszy sposób kodowania. Możemy skorzystać z opcji wyszukiwania tekstu Retrieval $\rightarrow$ Text Retrieval, znajdującej się w głównym pasku zadań (ilustr. 21).

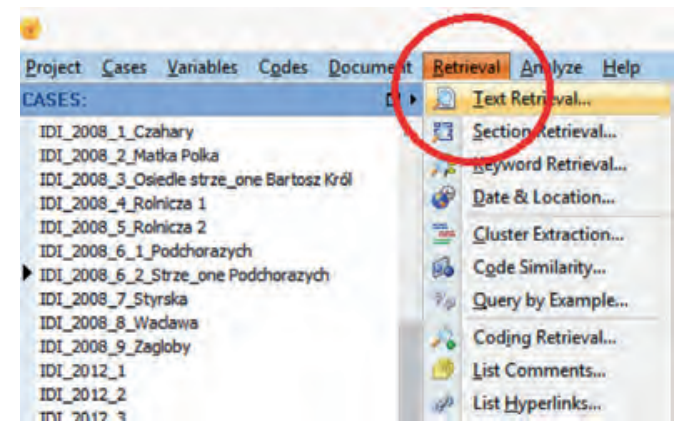

Ilustr. 21. Wyszukiwanie tekstu

Źródło: opracowanie własne

W oknie, które się pojawi, należy wpisać wyraz lub frazę, które chcemy odszukać. Przykładowo w przypadku badań na temat gated communities wyszukiwano takie wyrazy, jak: przyczyna, powód, motyw itp. Należy również zaznaczyć jednostkę, która ma być wyszukana, a mianowicie, czy ma być to cały dokument, ustęp (akapit), zdanie czy zakodowana część tekstu. Ponadto możemy wskazać, czy poszukiwania mają ograniczyć się tylko do jeszcze niezakodowanego tekstu czy objąć jego całość (ilustr. 22).

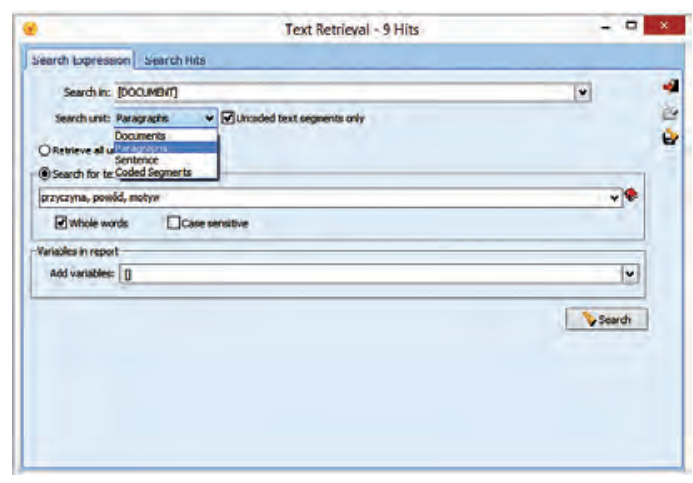

Ilustr. 22. Wyszukiwanie tekstu (cd.)

Źródło: opracowanie własne

W dalszej kolejności wyświetli się okno z otrzymanymi wynikami przedstawionymi w formie tabeli (ilustr. 23). Po zapoznaniu się z wybranymi fragmentami można je również automatycznie zakodować - należy rozwinąć opracowane 
wcześniej drzewo kodowe i wybrać nazwę kodu, którą chcemy przypisać wyszukanym fragmentom. Obok okna z wybraną nazwą kodu znajdują się symbole: jednego i dwóch markerów, wybór opcji pierwszej pozwala wybrać fragmenty, które chcemy zakodować za pomocą wskazanego kodu (Code selected hit), natomiast druga opcja (Code all hits) umożliwi nam zakodowanie wszystkich fragmentów wyszukanych przez program.

Funkcja wyszukiwania i automatycznego kodowania w znacznym stopniu przyśpiesza i ułatwia kodowanie, w szczególności w badaniach, w których w jasny sposób mamy określone informacje, które chcemy znaleźć. W przypadku badań nad osiedlami zamkniętymi, gdy przede wszystkim koncentrowano się na motywach, wspólnotowości, a także wadach i zaletach, w znacznym stopniu przyśpieszyło to proces kodowania. Należy jednak pamiętać, że opcja ta nie zastąpi rzetelnego przeglądu transkrypcji przez badacza. Co więcej, wymaga ona od niego szczegółowego zapoznania się z wyszukanymi fragmentami i przeanalizowania, czy można im przypisać dany kod. Jednocześnie warto dodać, że jest to tylko jedna z licznych opcji, która umożliwia wyszukiwanie tekstu w programie QDA Miner.

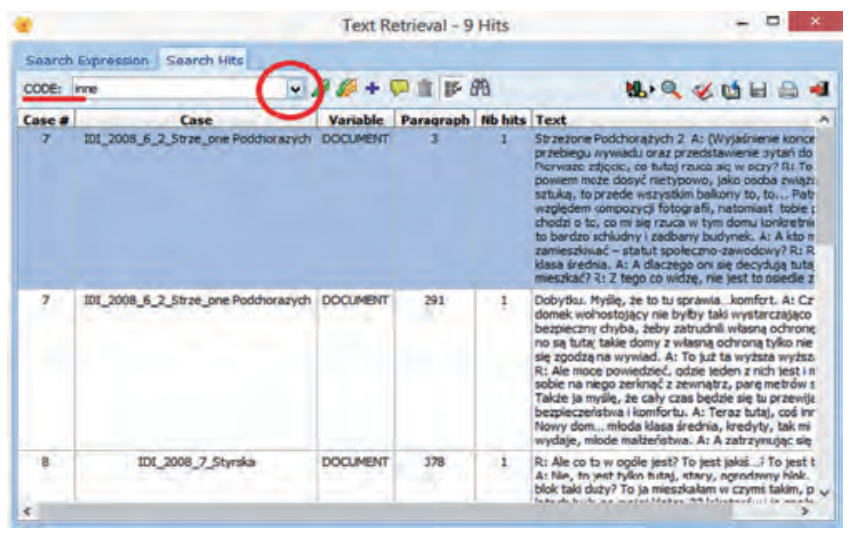

Ilustr. 23. Kodowanie wyszukanych akapitów

Źródło: opracowanie własne

\section{Analizowanie zakodowanego materiału}

Mając zakodowany materiał, można rozpocząć pracę analityczną. QDA Miner ułatwia nam rozpoczęcie analizy poprzez narzędzia umożliwiające wyselekcjonowanie materiału do dalszej pracy. Opcja Retrieval $\rightarrow$ Coding Retrieval umożliwia przejrzenie wszystkich fragmentów zakodowanych jednym bądź kilkoma kodami. Wykorzystując powyższą funkcję, program przedstawi wszystkie 
fragmenty, którym nadaliśmy wybraną etykietę (kod). Na tym etapie możemy ponownie zweryfikować, czy poprawnie zakodowaliśmy materiał, a także rozważyć możliwość połączenia analizowanego kodu z innym kodem bądź rozłączenia go na dwa bądź więcej niezależnych kodów (ilustr. 24).

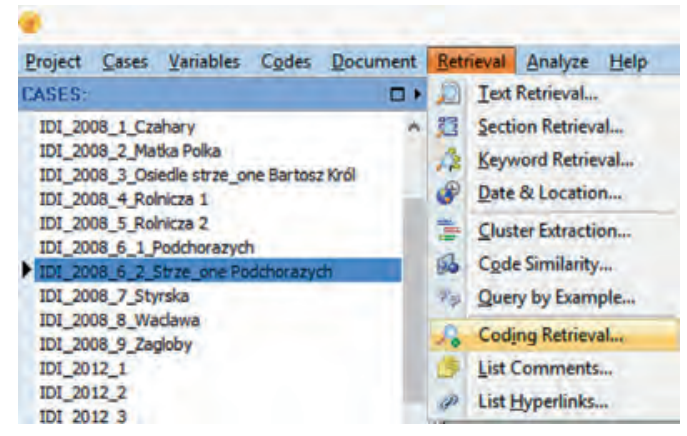

Ilustr. 24. Przegląd zakodowanych kodów Źródło: opracowanie własne

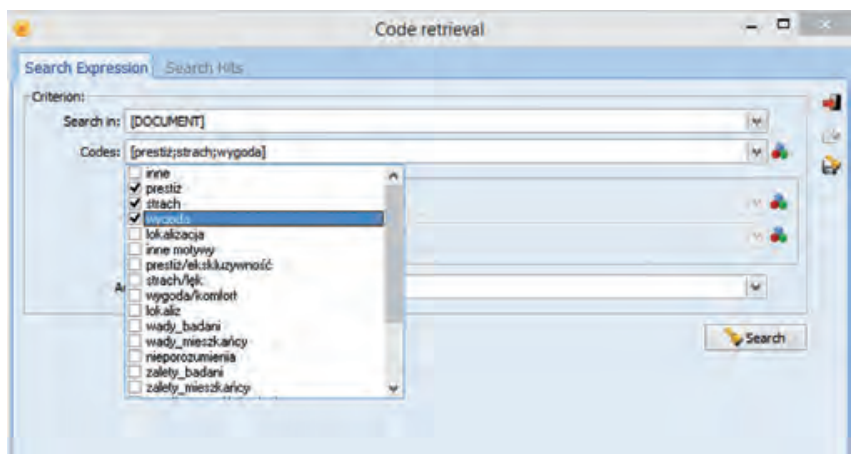

Ilustr. 25. Przegląd zakodowanych kodów (cd.)

Źródło: opracowanie własne

Ponadto opcja ta umożliwia wykorzystanie warunku (Condition - if), którego zastosowanie może zawęzić wyszukiwanie do przypadków, które np. pokrywają się z fragmentami zakodowanymi innym wybranym przez nas kodem (equel to), zawierają je w sobie (enclosing), zawierają się w nich (included in), zachodzą na siebie (overlapping), poprzedzają je (followed by), występują po nich (preceded by) albo pojawiają się blisko nich (near). Funkcja ta może zostać w różny sposób wykorzystywana w zależności od specyfiki i potrzeb badania (ilustr. 25). Dodatkowo oprócz samego przeglądu fragmentów zakodowanych za pomocą danej etykiety możliwe jest uwzględnienie poszczególnych zmiennych oraz ich wartości w ramach wyszukiwania (ilustr. 26). Podobnie jak w przypadku wyszukiwania 
tekstu wyniki przedstawione zostaną w formie tabelarycznej (por. ilustr. 23), co więcej również wykorzystując tę funkcję, możliwe jest przekodowanie wyszukanych fragmentów bądź przypisanie im całkowicie nowej etykiety (kodu).

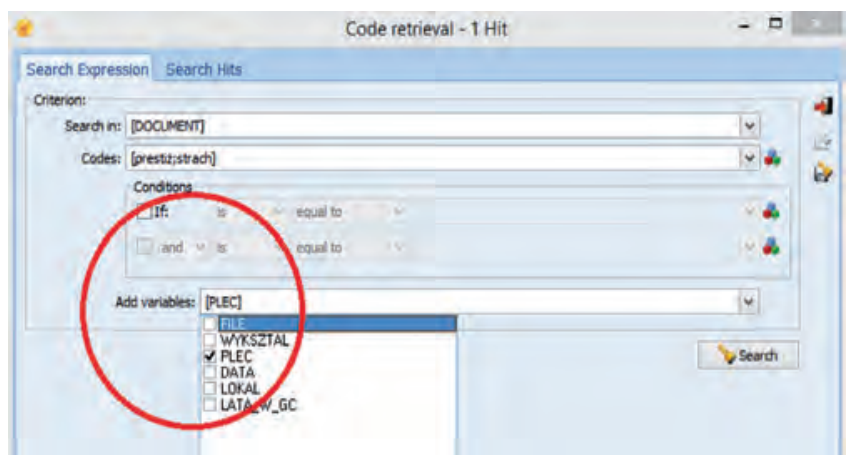

Ilustr. 26. Przegląd zakodowanych kodów z uwzględnieniem zmiennych i ich wartości

Źródło: opracowanie własne

Warto wspomnieć o możliwości wygenerowania z zakodowanych i wybranych $w$ trakcie wyszukiwania fragmentów tekstu raportu $w$ formacie tekstowym, a także wyeksportowania wybranych fragmentów do nowego dokumentu, tj. utworzenia nowego projektu w programie, w którym wstępnie zakodowane materiały mogą zostać poddane szczegółowemu kodowaniu.

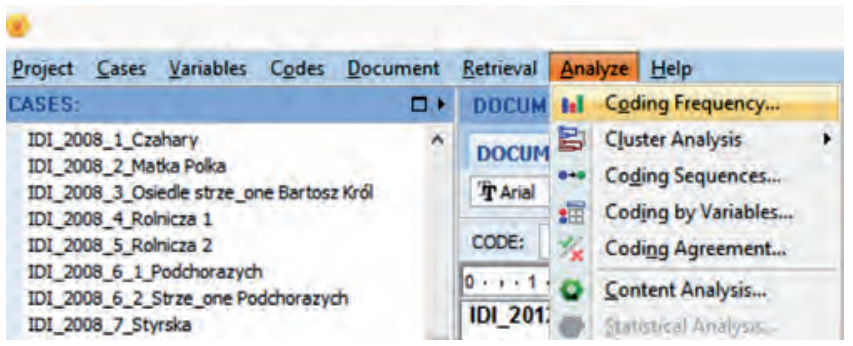

Ilustr. 27. Analiza częstości występowania kodów

Źródło: opracowanie własne

Przedstawiona funkcja Coding Retrieval umożliwia, zgodnie z samą nazwą, wyszukanie fragmentów tekstu zakodowanych za pomocą danego kodu bądź kodów, natomiast program oferuje jeszcze dodatkowe opcje do analizy zebranego materiału, które znajdują się w zakładce Analyze, w górnym pasku zadań. Jedną z podstawowych analiz, którą przeprowadzono w ramach badania łódzkich osiedli zamkniętych, była analiza częstości występowania danego kodu. Pozwala ona 
na zorientowanie się, które z kodów i z jaką częstotliwością występowały w analizowanym materiale. Aby skorzystać z tej funkcji, z zakładki Analyze należy wybrać opcję Coding Frequency (ilustr. 27). Funkcja umożliwia przedstawienie częstości występowania wszystkich albo tylko wybranych kodów. W przypadku tej drugiej opcji niezbędne jest rozwinięcie wszystkich kodów, które były wykorzystywane w badaniu i zaznaczenie tych, których częstość chcemy zweryfikować. Ponadto można skorzystać z opcji, która pozwala ograniczać zliczanie kodów do takich, które występują co najmniej $n$ razy (ilustr. 28). Z opcji tej można korzystać w zależności od specyfiki badania, np. jeżeli zależy nam na wyborze tylko tych kodów, które pojawiają się najczęściej.

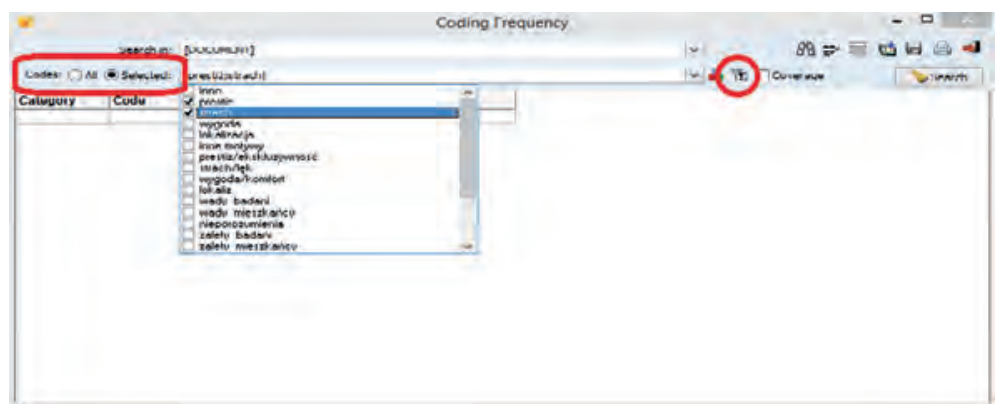

Ilustr. 28. Analiza częstości występowania kodów (cd.)

Źródło: opracowanie własne

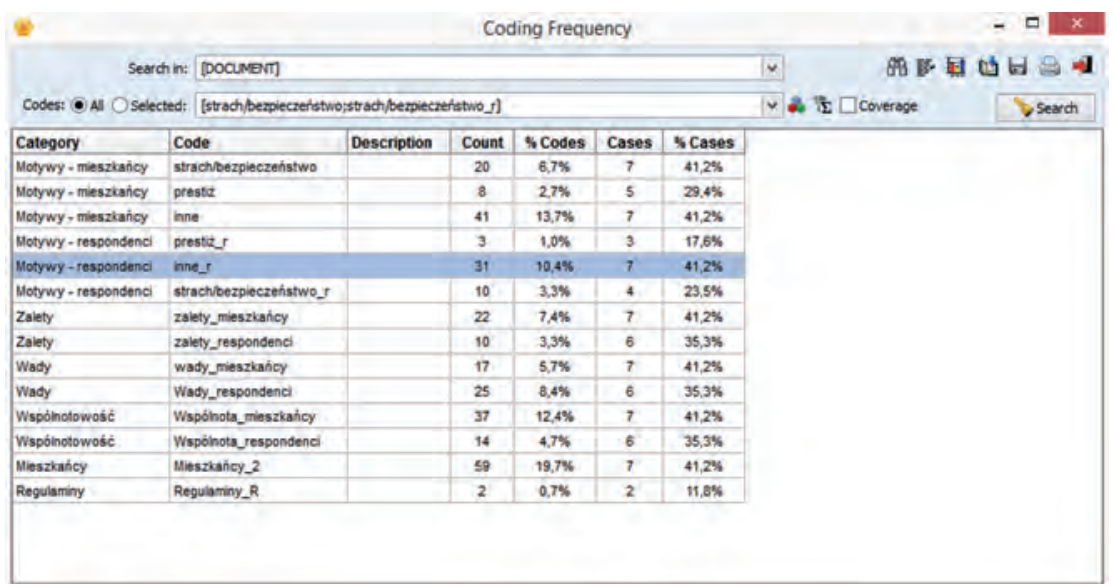

Ilustr. 29. Wyniki analizy częstości występowania kodów ${ }^{8}$

Źródło: opracowanie własne

${ }^{8}$ Zaprezentowane wyniki dotyczą innego projektu badawczego dotyczącego osiedli zamkniętych, stąd występują pewne różnice w nazewnictwie kodów. 
W ramach funkcji Coding Frequency, podobnie jak w przypadku opcji Coding Retrieval, wyniki zostaną zaprezentowane w tabeli (ilustr. 29), ale istnieje również możliwość przedstawienia ich w formie graficznej w postaci wykresów słupkowych, kołowych itp. (ilustr. 30-31). Dodatkowo w tym przypadku możemy skorzystać z funkcji wygenerowania raportu w formie tekstowej i wyeksportowania wyszukanych danych do nowego dokumentu, w którym można będzie przeprowadzić dodatkowe kodowanie wybranych fragmentów, np. w przypadku materiału zebranego w ramach badania dotyczącego gated communities w pierwszej kolejności można byłoby zakodować wybrane fragmenty kodem: motyw/przyczyna, w dalszej, korzystając z funkcji Coding Frequency lub Coding Retrieval, możliwe byłoby wyszukanie fragmentów zakodowanych tym kodem, a następnie importowanie ich do nowego dokumentu, w którym należałoby przeprowadzić dodatkowe kodowanie mające na celu zidentyfikowanie typów i rodzajów motywów oraz przyczyn wymienianych przez badanych, np. prestiż, bezpieczeństwo, komfort itp.
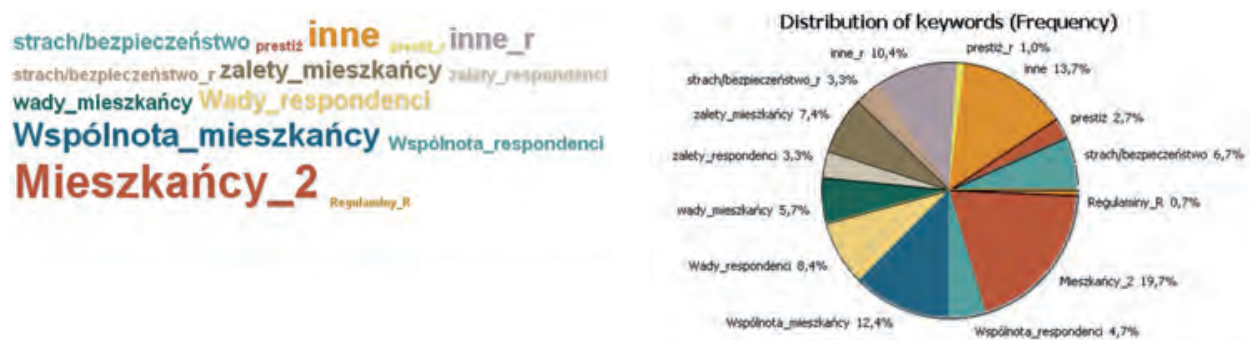

Ilustr. 30. i 31. Sposoby graficznej prezentacji danych

Źródło: opracowanie własne

Ostatnią przeprowadzoną analizą związaną z problematyką gated communities, a zarazem jedną z najciekawszych, które oferuje program QDA Miner, była analiza częstości występowania kodów według zmiennych (Coding by Variables). Pozwala ona na przedstawienie częstości występowania wybranego kodu lub kodów w powiązaniu z wartościami wybranej zmiennej lub zmiennych. Aby skorzystać z tej analizy, z zakładki Analyze należy wybrać opcję Coding by Variables, a następnie wybrać kod oraz zmienną (Tabulate with), z jaką chcemy go skrzyżować (ilustr. 32). W ramce, która się wyświetli (Table content), należy wybrać ustawienia tabeli, a mianowicie czy wyniki mają dotyczyć liczebności kodu (Code Frequency), liczby występujących przypadków (Code occurence (cases)), liczby zakodowanych słów (Word count) czy ich odsetka w dokumentach o danej wartości zmiennej (Percentage of words). Ponadto w pasku Display należy wybrać, czy wyniki mają być przedstawione w liczbach bezwzględnych (Count), w procentach przedstawionych w wierszach (Row percent), kolumnach (Column percent) czy całej tabeli (Total percent) (ilustr. 33). 


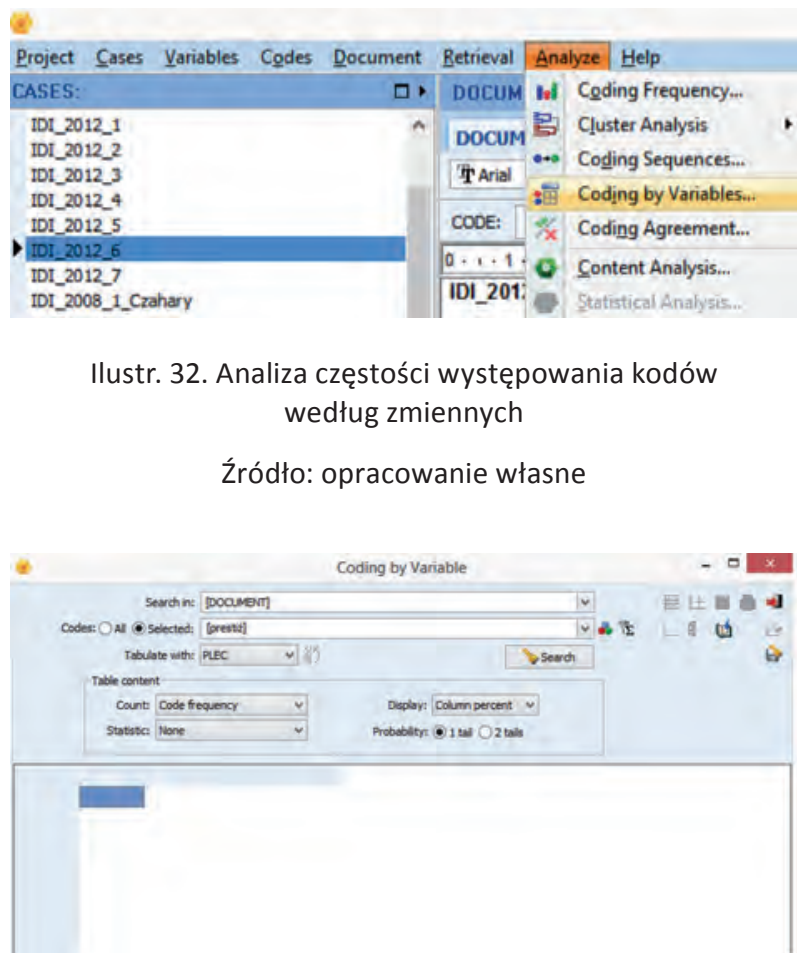

Ilustr. 33. Analiza częstości występowania kodów według zmiennych (cd.)

Źródło: opracowanie własne

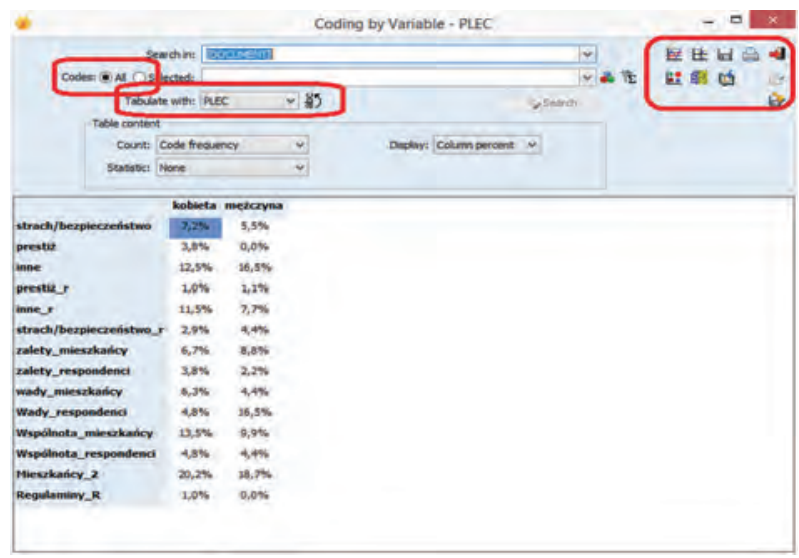

Ilustr. 34. Wyniki analizy częstotliwości występowania kodów według wybranej zmiennej

Źródło: opracowanie własne 


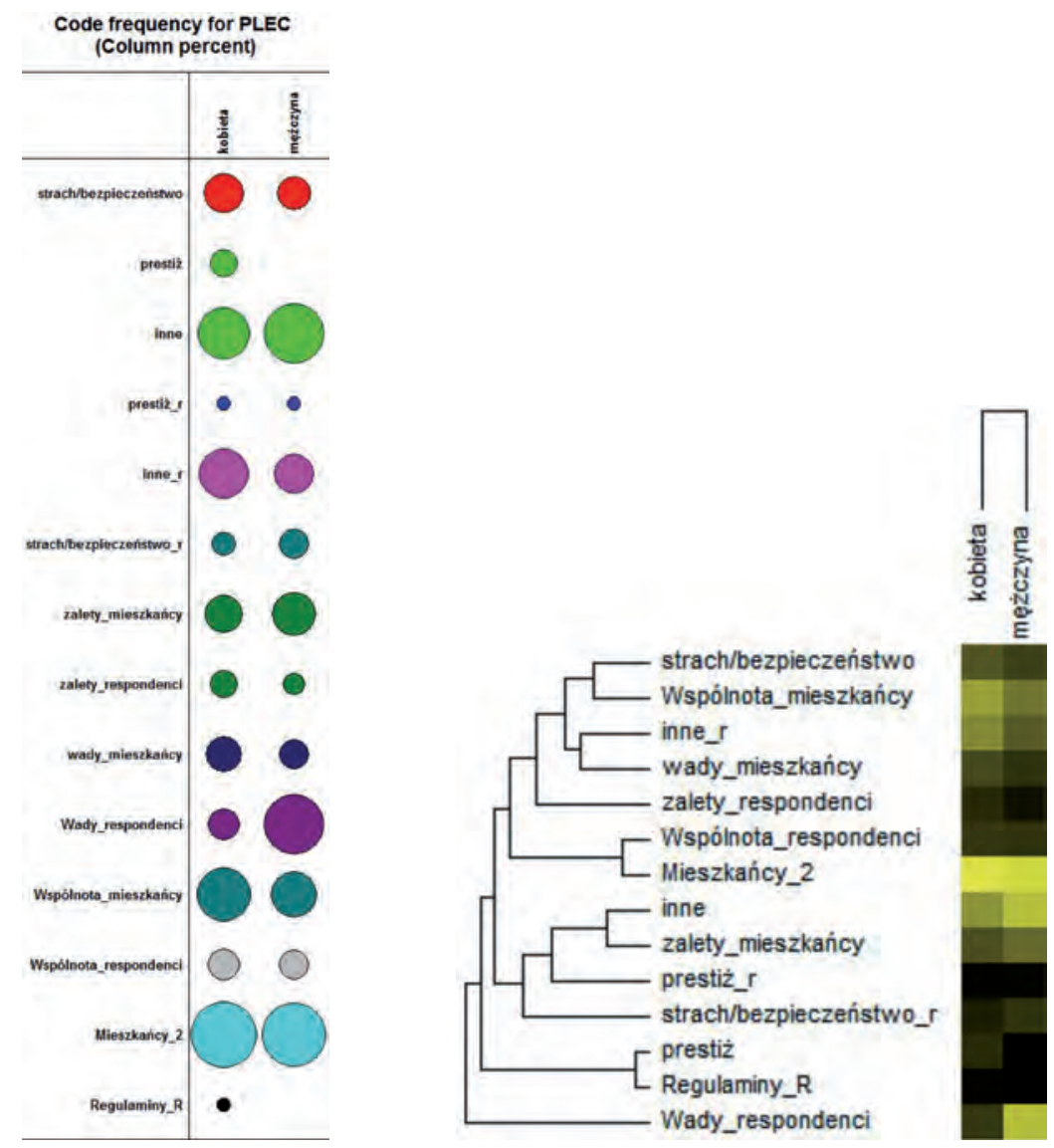

Ilustr. 35. i 36. Graficzna prezentacja wyników analizy częstości występowania kodów według zmiennej

Źródło: opracowanie własne

\section{Podsumowanie}

Wydaje się, że konflikt między badaczami jakościowymi a ilościowymi w znacznym stopniu został zażegnany, zaś techniki jakościowe zyskały podobny status do ilościowych. Każda z tych grup technik badawczych ma swoje zalety i wady. Techniki jakościowe lepiej nadają się do badania zjawisk, które wymagają bliższego poznania i zrozumienia, z kolei ilościowe do innych, chociażby opinii społeczeństwa na dany temat. W celu wykorzystania zalet ich obu można wykorzystać tzw. Mixed Method Research albo triangulację. W przypadku tych dwóch metod coraz większy wpływ na analizowanie materiału zebranego za ich pomocą mają nowoczesne 
technologie. Jednym z przykładów nowoczesnych narzędzi wpływających na proces analizy może być przedstawiony w niniejszym artykule program QDA Miner, który należy do coraz szybciej rozwijającej się rodziny oprogramowania komputerowego wspierającego analizę danych jakościowych CAQDAS (Computer-Assisted Qualitative Data Analysis Software). Jak zauważa Jakub Niedbalski (2013), nowoczesne technologie odciskają swoje piętno już nie tylko na naukach ścisłych i przyrodniczych, lecz także społecznych, w tym na praktykach badaczy jakościowych. Świadczy o tym chociażby coraz większa liczba dostępnych na rynku programów, a także publikacji i konferencji naukowych. Należy jednak zauważyć, że w przypadku nauk społecznych nowoczesne technologie początkowo zaczęły być wykorzystywane przez badaczy prowadzących badania ilościowe, natomiast początek rozwoju CAQDAS można datować na lata 80. XX w. W tym miejscu należy wspomnieć o pierwszej wersji programu NUDIST, która pojawiła się w roku 1981 (Brosz 2012). Jak podkreślą Niedbalski i Ślęzak (2012: 128):

Wspomagana komputerowo analiza danych jakościowych (Computer-Assisted Qualitative Data Analysis Software [CAQDA]) ma więc już swoją tradycję, a jej rozwój można rozpatrywać w dwóch aspektach: technologicznym oraz metodologiczno-analitycznym.

W niniejszym artykule starano się ukazać oba powyższe aspekty programu QDA Miner - jego możliwości techniczne, a także dostosowanie do potrzeb i oczekiwań badacza oraz wpływ na cały proces badawczy. Przed przedstawieniem wniosków bezpośrednio dotyczących omawianego programu warto jednak skrótowo odnieść się do wad i zalet komputerowo wspomaganej analizy danych jakościowych prezentowanych w literaturze przedmiotu. Z jednej strony podkreśla się, że jej podstawową zaletą jest przede wszystkim szybkość kodowania, a także dyscyplina badawcza. Oprogramowanie CAQDAS umożliwia przeprowadzenie uporządkowanej analizy, przedstawienie częstości występowania danego zjawiska, skuteczne przeszukanie całości analizowanych tekstów, co w efekcie ogranicza możliwość pojawienia się zarzutu, że wyniki ograniczają się jedynie do wyboru anegdot wspierających interpretację badacza. Ponadto wykorzystanie programów do jakościowej analizy tekstu umożliwia efektywniejszą pracę zespołową, m.in. poprzez możliwość wypracowania zgodnego stanowiska wobec znaczenia wykorzystywanych kategorii, co z kolei pozytywnie wpływa na rzetelność całego badania (Seale 2009). Z drugiej strony można spotkać się też z kilkoma zastrzeżeniami i wadami odnoszonymi do CAQDAS, a mianowicie z zapośredniczonym przez program dostępem do materiału empirycznego. Podkreśla się, że badacze prowadzący analizy „na papierze” mogą mieć poczucie bliższej styczności z wypowiedziami badanych. Kolejnym zarzutem jest zbyt duży wpływ metodologii teorii ugruntowanej bądź ogólne ograniczenie i zawężenie perspektywy badawczej, a także zbyt silny nacisk położony na procedury kodowania 
i wyszukiwania danych (Seale 2009; Gibbs 2011). Pojawiają się również zastrzeżenia, że część operacji przeprowadzonych z pomocą specjalistycznego oprogramowania CAQDAS można byłoby wykonać za pomocą zwykłych edytorów tekstów. Ponadto w przypadku małych partii danych, wykorzystywanie pakietów komputerowych jest raczej mało przydatne (Gibbs 2011). Powyżej przedstawione zastrzeżenia przyczyniają się do powstawania obaw związanych z wykorzystywaniem programów do jakościowej analizy danych. Jakub Niedbalski (2013) zwraca uwagę m.in. na wątpliwości części badaczy jakościowych w zakresie praktycznego zastosowania oprogramowania CAQDAS oraz na pewne bariery mentalne przejawiające się nieufnością do wykorzystywania nowoczesnych technologii w tradycyjnych metodach naukowych. Zdaniem Gregora Wiedemanna (2013) wykorzystanie CAQDAS może się kojarzyć z analizą tekstu przebiegającą według wzorów analiz dokonywanych na liczbach za pomocą programu SPSS, natomiast badaczom jakościowym zależy przede wszystkim na tym, aby unikać redukcjonistycznej epistemologii pozytywistycznej. Możliwość wykorzystania w analizie większej liczby przypadków nie jest również postrzegane jako coś pożądanego i koniecznego. Badacze jakościowi, aby zgłębić przedmiot ich badań, nie powinni koncentrować się na jak największej liczbie przypadków, lecz na jak najbardziej zróżnicowanych przypadkach (Wiedemann 2013).

W tym miejscu warto ustosunkować się do przedstawionych w literaturze zalet i wad CAQDAS i odnieść je do doświadczeń wynikających z pracą w programie QDA Miner. Przede wszystkim należy się zgodzić, że wykorzystywanie programu w znacznym stopniu przyśpiesza proces kodowania, ale trzeba zauważyć, że warunkiem koniecznym jest szczegółowe zapoznanie się ze specyfiką programu, jego funkcjami, możliwościami itp. Jest to zajęcie czasochłonne i procesualne, a próba przeprowadzenia pierwszej analizy za pomocą programu, którego dopiero się uczymy, może trwać dłużej niż w przypadku wykorzystania metody „ołówka i papieru”. Niemniej z każdym kolejnym projektem oszczędności czasu na pewno będą znaczne. Program QDA Miner jest również skutecznym narzędziem do porządkowania i strukturyzowania zebranego materiału. Warto wspomnieć o możliwości dodawania zmiennych służących do opisu poszczególnych przypadków oraz umożliwiających łatwą ich identyfikację. Niewątpliwie oprogramowanie CAQDAS pozytywnie wpływa na dyscyplinę projektu badawczego. W literaturze przedmiotu podkreśla się jednak, że w przypadku badań jakościowych żaden program nigdy nie zastąpi badacza i jego interpretacji. Z powyższą tezą nie należy dyskutować, ale należy zwrócić uwagę, że opisane $w$ artykule funkcje analizy mogą w znacznym stopniu wesprzeć i zainspirować badacza w procesie interpretacyjnym. Na szczególną uwagę zasługuje możliwość krzyżowania kodów z poszczególnymi zmiennymi i ich wartościami, czyli coś, co w przypadku tradycyjnej analizy jest bardzo trudne, a niemalże niewykonalne. 
Odnosząc doświadczenia wynikające z pracy w programie QDA Miner do pojawiających się w literaturze zarzutów, należy zaznaczyć, że obecnie coraz częściej mamy do czynienia z zapośredniczoną „stycznością” w przypadku książek, gazet, magazynów itp., co przekłada się również na styczność z materiałem badawczym. Podczas badań nad łódzkimi osiedlami zamkniętymi kontakt z materiałem zapośredniczonym za pomocą monitora i interfejsu programu nie stanowił większego problemu. W przypadku omawianego programu niesłuszny wydaje się również zarzut dotyczący monopolizacji CAQDAS przez metodologię teorii ugruntowanej. W omawianych badaniach przed przystąpieniem do kodowania, na podstawie wcześniejszej konceptualizacji, opracowano początkową listę kodów, co nie wiązało się z żadnymi problemami w trakcie pracy w programie. Co więcej, można odnieść wrażenie, że specyfika oprogramowania, w tym dodawania kodów, sprzyja raczej takiemu podejściu niż klasycznemu kodowaniu otwartemu w ramach metodologii teorii ugruntowanej. Natomiast w odniesieniu do zarzutu o znacznej koncentracji na kodowaniu i wyszukiwaniu tekstu należy zauważyć, że program QDA Miner posiada liczne dodatkowe funkcje analityczne. Trzeba jednak zaznaczyć, odwołując się do przytaczanej wcześniej opinii Wiedemanna, że jakościowa analiza tekstu dokonywana za pomocą specyficznego oprogramowania nigdy nie powinna przebiegać według wzorów analiz dokonywanych na liczbach za pomocą pakietów statystycznych. Oprogramowanie CAQDAS stanowi znaczne wsparcie dla badacza, ale raczej nigdy go nie zastąpi w interpretacji. Odpowiadając na zarzut, że program QDA Miner można zastąpić zwykłym edytorem tekstu, trzeba stwierdzić, że samo przeprowadzenie jakościowej analizy mogłoby być możliwe, ale nie na takim poziomie, na jakim można to zrobić z wykorzystaniem QDA Miner.

Konkludując, można postawić tezę, że niebawem takie programy, jak QDA Miner, MAXQDA, NVivo staną się dla badaczy jakościowych tym, czym SPSS i Statistica dla badaczy ilościowych.

\section{Bibliografia}

Babbie Earl (2007), Badania społeczne w praktyce, przeł. Witold Betkiewicz, Marta Bucholc, Przemysław Gadomski, Jacek Haman, Agnieszka Jasiewicz-Betkiewicz, Agnieszka Kłoskowska-Dudzińska, Michał Kowalski, Maja Mozga, Wydawnictwo Naukowe PWN, Warszawa.

Blakely Edward J., Snyder Mary Gail (1997), Fortress America: Gated Communities in the United States, Brookings Institution Press Washington, D.C., Lincolne Institute of Land Policy Cambrige, Massachusetts.

Brosz Maciej (2012), Komputerowe wspomaganie badań jakościowych. Zastosowanie pakietu NVivo w analizie materiałów nieustrukturalizowanych, „Przegląd Socjologii Jakościowej”, t. VIII, nr 1, s. 98-125; www.qualitativesociologyreview.org/PL/Volume18/PSJ_8_1_Brosz. pdf [dostęp: 25.04.2014]. 
Burke Johnson R., Onwuegbuzie Anthony J., Turner Lisa A. (2007), Toward a Definition of Mixed Methods Research, "Journal of Mixed Methods Research", 1, s. 112-133.

Collier John, Collier Malcolm (1986), Visual Anttropology: Photography as a Research Method, University of New Mexico Press, Albuquerque.

Denzin Norman (1970), The Research Act: Theoretical Introduction to Sociological Methods, Aldine Publishing Co., Chicago.

Flick Uwe (2010), Projektowanie badania jakościowego, przeł. Paweł Tomanek, Wydawnictwo Naukowe PWN, Warszawa.

Gądecki Jacek (2007), Za murami - krytyczna analiza dyskursu na temat osieli typu gated communities w Polsce, [w:] Bohdan Jałowicki, Wojciech Łukowski (red.), Gettoizacja polskiej przestrzeni miejskiej, Wydawnictwo Naukowe Scholar, Warszawa.

Gibbs Graham (2011), Analizowanie danych jakościowych, przeł. Maja Brzozowska-Brywczyńska, Wydawnictwo Naukowe PWN, Warszawa.

Jałowiecki Bohdan, Szczepański Marek S. (2006), Miasto i przestrzeń w perspektywie socjologicznej, Wydawnictwo Naukowe Scholar, Warszawa.

Konecki Krzysztof Tomasz (2012), Metodologia teorii ugruntowanej - strategia analizy badań jakościowych, [w:] Krzysztof Tomasz Konecki, Piotr Chomczyński (red.), Słownik socjologii jakościowej, Difin SA, Warszawa.

Konecki Krzysztof Tomasz (2000), Studia z metodologii badań jakościowych. Teoria ugruntowana, Wydawnictwo Naukowe PWN, Warszawa.

Koseła Krzysztof (1989), Wywiad z interpretacja fotogramów, [w:] Antoni Sułek, Anna Wyka (red.), Poza granicami socjologii ankietowej, Wyd. Instytutu Socjologii UW, Warszawa.

Kvale Steinar (2010), Prowadzenie wywiadów, przeł. Agata Dziuban, Wydawnictwo Naukowe PWN, Warszawa.

Lofland John, Lofland Lyn H. (1995), Analyzing Social Settings: A guide to Qualitative Observation and Analysis, wyd. 3, Wadsworth, Belmont.

Niedbalski Jakub (2012), Wywiad swobodny (Free interview), [w:] Krzysztof Tomasz Konecki, Piotr Chomczyński (red.), Słownik socjologii jakościowej, Difin SA, Warszawa.

Niedbalski Jakub (2013), Odkrywanie CAQDAS. Wybrane bezpłatne programy komputerowe wspomagajqce analizę danych jakościowych, Wydawnictwo Uniwersytetu Łódzkiego, Łódź.

Niedbalski Jakub, Ślęzak Izabela (2012), Analiza danych jakościowych przy użyciu programu NVivo a zastosowanie procedur metodologii teorii ugruntowanej, „Przegląd Socjologii Jakościowej", t. VIII, nr 1, s. 126-165; www.qualitativesociologyreview.org/PL/Volume18/PSJ_8_1_ Niedbalski_Slezak.pdf [dostęp: 25.10.2013].

Olechnicki Krzysztof (2003), Antropologia obrazu, Oficyna naukowa, Warszawa.

Scott John, Marshall Gordon (ed.), (2005), A Dictionary of Sociology, Oxford University Press, New York.

Seale Clive (2009), Wykorzystanie komputera w analizie danych jakościowych, [w:] David Silverman (red.), Prowadzenie badań jakościowych, przeł. Joanna Ostrowska, Wydawnictwo Naukowe PWN, Warszawa.

Słownik badawczy, http://dobrebadania.pl/slownik-badawczy.html?b=baza\&szczegolowo=155 [dostęp: 26.04.2014].

Wiedemann Gregor (2013), Opening up to Big Data: Computer-Assisted Analysis of Textual Data in Social Sciences, Forum Qualitative Sozialforschung / Forum: Qualitative Social Research, May, vol. 14, no. 2, art. 23; www.qualitative-research.net/index.php/fqs/article/ view/1949/3553 [dostęp: 25.04.2014]. 


\section{The Use of a Computer Program QDA Miner in the Analysis of Qualitative Research. The Example of Individual In-Depth Interviews with Residents of Gated Communities in Lodz}

Summary. The main purpose of this article is to present the process of the qualitative analysis using computer programme QDA Miner. The article presents the differences between analysis conducting in a traditional way and computer-assisted analytical process. For this purpose, there have been used individual in-depth interviews conducted with residents of so-called gated communities.

At this point, it is worth noting that the computer programmes (CAQDAS packages) supporting the work of qualitative researchers are becoming more and more popular, including also Polish researchers. Furthermore, more often articles on practical use of such programmes might be found in Polish scientific journals. Most of them discussed the capacities of such programmes as NVivo, Atlas.ti, MAXqda or Opencode. On the other hand, there are not many articles on QDA Miner, what might be explained by its less popularity. Therefore it seems reasonable to present the capacity of this programme in assisting qualitative data analysis.

Keywords: gated communities, qualitative research, qualitative data analysis, computer-assisted data analysis, QDA Miner. 